\title{
Semi-volatile and highly oxygenated gaseous and particulate organic compounds observed above a boreal forest canopy
}

\author{
Ben H. Lee ${ }^{1}$, Felipe D. Lopez-Hilfiker ${ }^{1, \text { a }}$, Emma L. D'Ambro ${ }^{2}$, Putian Zhou ${ }^{3}$, Michael Boy ${ }^{3}$, Tuukka Petäjä ${ }^{3}$, \\ Liqing $\mathrm{Hao}^{4}$, Annele Virtanen ${ }^{4}$, and Joel A. Thornton ${ }^{1}$ \\ ${ }^{1}$ Department of Atmospheric Sciences, University of Washington, Seattle, WA, USA \\ ${ }^{2}$ Department of Chemistry, University of Washington, Seattle, WA, USA \\ ${ }^{3}$ Institute for Atmospheric and Earth System Research/Physics, Faculty of Science, University of Helsinki, Helsinki, Finland \\ ${ }^{4}$ Department of Physics, University of Eastern Finland, Kuopio, Finland \\ anow at: TofWerk AG, Thun, Switzerland
}

Correspondence: Joel A. Thornton (thornton@atmos.uw.com)

Received: 3 March 2018 - Discussion started: 4 April 2018

Revised: 13 July 2018 - Accepted: 24 July 2018 - Published: 15 August 2018

\begin{abstract}
We present hourly online observations of molecular compositions $\left(\mathrm{C}_{x} \mathrm{H}_{y} \mathrm{O}_{z} \mathrm{~N}_{0-1}\right)$ and abundances of oxygenated organic species in gas and submicron particle phases from April to June of 2014 as part of the Biogenic AerosolsEffects on Cloud and Climate (BAECC) campaign. Measurements were made using the Filter Inlet for Gases and AEROsols coupled to a high-resolution time-of-flight iodideadduct ionization mass spectrometer (FIGAERO-CIMS) located atop a $35 \mathrm{~m}$ tall tower, about $10 \mathrm{~m}$ above a boreal forest canopy at the SMEAR II research station in Hyytiälä, Finland. Semi-volatile and highly oxygenated multifunctional (HOM) organic species possessing from 1 up to 20 carbon atoms, and with as few as 2 and as many as 16 oxygen atoms, were routinely observed. Utilizing non-negative matrix factorization, we determined that $>90$ and $>99 \%$ of the organic mass in the gas and particle phases, respectively, exhibited one of three distinct diel trends: one in which abundances were enhanced at daytime, another in the early morning hours, and thirdly during nighttime. Particulate organic nitrates contributed $\sim 35 \%$ to the total organic aerosol mass loading at night during BAECC, much higher than observed by the same instrument package at a mixed-deciduous forest site in the southeastern US that experienced higher nighttime concentrations of nitrogen oxides. Unique HOM monomers (defined here as those with 10 carbon and 7 or more oxygen atoms) and dimers (at least 16 carbon atoms), with and without a nitrogen atom, were found in most of the three subgroups of both phases. We show the potential
\end{abstract}

to connect these groupings of compounds based on their distinct behavior in time to the expected chemical conditions (biogenic VOC precursor, oxidant type, etc.) responsible for their production. A suite of nitrated dimer-like compounds was detected in both the gas and particle phases, suggesting a potential role for the formation of low-volatility organics from $\mathrm{NO}_{3}$-radical-driven, as well as daytime $\mathrm{NO}$-influenced, monoterpene chemistry.

\section{Introduction}

The world's forests emit about a petagram of $\mathrm{C}$ per year in the form of hydrocarbons $\left(\mathrm{C}_{x} \mathrm{H}_{y}\right)$ (Guenther et al., 2006), an amount comparable to that stored annually in the biome due to the growth of organic matter (Steffen et al., 1998). Isoprene $\left(\mathrm{C}_{5} \mathrm{H}_{8}\right)$ and monoterpenes $\left(\mathrm{C}_{10} \mathrm{H}_{16}\right)$ together account for more than half of the total biogenic hydrocarbon emissions (Guenther et al., 2012). Upon their release into the atmosphere, they undergo oxidation reactions over timescales of several minutes to hours during which hundreds, if not thousands, of products possessing unique molecular compositions $\left(\mathrm{C}_{x} \mathrm{H}_{y} \mathrm{O}_{z} \mathrm{~N}_{0,1}\right)$ are generated due to fragmentation, functionalization, and/or accretion (Goldstein and Galbally, 2007; Kroll et al., 2011). Identifying the molecular compositions of the cascade of compounds unleashed during this process is key to determining their chemical properties such as saturation vapor pressure and reactivity, which are funda- 
mental to assessing their potential for forming and growing nanometer-sized atmospheric particles and the timescales of their influence downwind of the region of emission.

Boreal forests, located at the mid to high latitudes, are undergoing rapid warming (Bonan, 2008) with longer growing seasons that act to strengthen the emission rates of biogenic volatile organic compounds (VOCs) (Guenther et al., 2006). It is widely recognized that the condensation or reactive uptake of low-volatility organic vapors, derived from the oxidation of BVOC, drives the growth of Aitken mode particles to cloud condensation nuclei (CCN) sizes in remote continental and some coastal regions near marine stratus (Hallquist et al., 2009; Jimenez et al., 2009; Riipinen et al., 2011). A thorough understanding of aerosol particle formation rate, particle growth rate, lifetime, and fate is, therefore, crucial for quantitatively assessing their impact on $\mathrm{CCN}$ activity that in turn influences regional radiative and hydrological budgets (Heald et al., 2008; Paasonen et al., 2013; Spracklen and Rap, 2013). Large regions of the world's boreal forests, relative to temperate forests, are (i) minimally affected by anthropogenic pollutants, which can alter the chemical pathways by which biogenic VOC oxidation proceeds, and (ii) emit large quantities of terpenes, namely monoterpenes and sesquiterpenes $\left(\mathrm{C}_{15} \mathrm{H}_{24}\right)$, that, once oxidized, readily form condensable material that leads to the formation and growth of secondary organic aerosol (SOA) (Ehn et al., 2014; Kavouras et al., 1998).

We deployed the Filter Inlet for Gases and AEROsols (FIGAERO) coupled to a high-resolution chemical ionization time-of-flight mass spectrometer (HRToF-CIMS) as part of the Biogenic Aerosols-Effects on Clouds and Climate (BAECC) campaign, which took place in Hyytiälä, Finland, during April and May of 2014. The FIGAERO HRToF-CIMS, henceforth referred to as FIGAERO-CIMS, provided online measurements of molecular compositions $\left(\mathrm{C}_{x} \mathrm{H}_{y} \mathrm{O}_{z} \mathrm{~N}_{0-1}\right)$ and abundances of the organic constituents of the gas and particle phases. We organize all of the organic constituents of the gas and particle phases into subgroups that are characterized by their behavior in time by utilizing a matrix factorization approach, similar to that of Yan et al. (2016), which employed positive matrix factorization (PMF) on gas-phase measurements made using the Atmospheric Pressure interface Time-Of-Flight mass spectrometer (APi-TOF, Aerodyne Research Inc. \& Tofwerk AG; Junninen et al., 2010). A number of previous studies have presented observations of the organic constituents of the gas phase at this site (Bianchi et al., 2017; Ehn et al., 2010, 2012). The hourly measurements of both phases afforded by the FIGAERO-CIMS allow us to more accurately determine the temporal behavior of organic molecules in the particle phase, and the relationship with their gas-phase counterparts.

\section{Methods}

Observations were made over a boreal forest in Hyytiälä, Finland $\left(61^{\circ} 50^{\prime} 36.73^{\prime \prime} \mathrm{N}, 24^{\circ} 17^{\prime} 16.25^{\prime \prime} \mathrm{E}\right)$, at the Station for Measuring Ecosystem-Atmosphere Relations (SMEAR II), a long-term field site dedicated to comprehensive measurements of reactive gases and aerosol particle characteristics since its inception in 1996 (Hari and Kulmala, 2005; Kulmala et al., 2000; Junninen et al., 2009). BAECC was an intensive field campaign organized by the US Department of Energy and the University of Helsinki, and took place from February to September of 2014 with the primary goal of assessing the sources and effects of aerosol particles formed from biogenic VOC (Petäjä et al., 2016). The history, stand age, tree species composition, and other aspects of the forest enveloping the SMEAR II site have been detailed in previous studies (Ilvesniemi and Liu, 2001; Kulmala et al., 2001). The deployment period for the FIGAERO-CIMS was between mid-April and early June of 2014, and will be the focus here.

The HRToF-CIMS instrumentation (Junninen et al., 2010; Lee et al., 2014; Yatavelli et al., 2012), the FIGAERO front end (Lopez-Hilfiker et al., 2014), their operation in the field coupled together (D'Ambro et al., 2017; Liu et al., 2016; Lopez-Hilfiker et al., 2016b), as well as its deployment during BAECC (Mohr et al., 2017; Schobesberger et al., 2016), are detailed elsewhere. Briefly, the FIGAERO-CIMS was located at the top of a $35 \mathrm{~m}$ tall scaffolding tower, on the southwestern edge of the top platform. Ambient particles were drawn in through a $2 \mathrm{~m}$ long stainless steel inlet $(22 \mathrm{~mm}$ inner diameter) at a flow rate of $2.5 \mathrm{slpm}$. A custom inertial impactor was used to remove particles $>\sim 2 \mu \mathrm{m}$ before collection on a $1 \mu \mathrm{m}$ pore size perfluorotetrafluoroethylene (PTFE) filter in the FIGAERO unit. Particle collections were conducted for $30 \mathrm{~min}$, during which the gas phase was measured by sampling ambient air at a flow rate of $22 \mathrm{slpm}$ through a $1 \mathrm{~m}$ long PTFE inlet (17 mm inner diameter). Particles were desorbed off of the FIGAERO filter by heating ultrahigh-purity $\mathrm{N}_{2}(2.5 \mathrm{slpm}$ through the FIGAERO PTFE filter) by $10^{\circ} \mathrm{C} \mathrm{min}^{-1}$ up to $200^{\circ} \mathrm{C}$. The desorption cycle lasted $60 \mathrm{~min}$, during which $\sim 20 \mathrm{slpm}$ was maintained to avoid stagnant air in the gas-phase inlet. Every fourth particle collection cycle was conducted with an additional particle filter upstream of the normal FIGAERO filter. This provided a way to correct for interfering background signals arising from semi- and non-volatile gases that can collect on filters and from the ionization source. A high-resolution timeof-flight aerosol mass spectrometer (AMS) (DeCarlo et al., 2006; Dunlea et al., 2009) was located inside a ground-based trailer near the base of the scaffolding tower. The copper inlet (4.4 $\mathrm{mm}$ inner diameter) to the AMS instrument was located $3.7 \mathrm{~m}$ off the canopy floor. The total flow through the AMS inlet was $1.09 \mathrm{slpm}$.

Given the challenges associated with obtaining reliable calibration sources for each of the hundreds of unique molecular compositions present upon oxidation of VOCs (Gold- 
stein and Galbally, 2007; Hunter et al., 2017) and detected by iodide-adduct ionization (Isaacman-VanWertz et al., 2017; Lopez-Hilfiker et al., 2016a), we do not attempt to close any mass budgets with the FIGAERO-CIMS measurements alone. For the purposes here, we apply a maximum sensitivity with which the instrument is capable of measuring any particular compound in order to obtain a lower limit on the concentration that is accounted for by the detected ion intensity within the mass spectrometer. The maximum sensitivity is determined by the highest rate of collision between the iodide reagent ion and the compound of interest in the ambient matrix, i.e., assuming formation of the adduct ion at the collision limited rate, no fragmentation, surface reactions, or losses of charge once clustered with the iodide ion (Lopez-Hilfiker et al., 2016a). While the collision cross section and thus the collision frequency will vary from compound to compound, we neglect this effect as it is on the order of a factor of 2 , and instead quote an uncertainty in the minimum concentration of $\pm 50 \%$. The focus of the work here is the distributions of molecular compositions that comprise the gas and particle phases with a specific emphasis on highly oxygenated molecules (HOM), how they evolve in time distinctly from one another, and the interpretation of these observations for their sources and sinks.

For the 584 identified organic carbon species $\left(\mathrm{OC}=\mathrm{C}_{x} \mathrm{H}_{y} \mathrm{O}_{z} \mathrm{~N}_{0}\right), x$ ranges from 1 to $20, y$ is an even number greater than or equal to $x$ but less than or equal to $2 x+2$, and $z$ is greater than or equal to 2 . For the 434 identified organic nitrate species $\left(\mathrm{ON}=\mathrm{C}_{x} \mathrm{H}_{y} \mathrm{O}_{z} \mathrm{~N}_{1}\right), x$ also ranges from 1 to $20, y$ is an odd number greater than or equal to $x$ but less than $2 x+2$, and $z$ is greater than or equal to 4 . We note that there are more ion peaks than represented here at the higher mass-to-charge ratios where the carbon number exceeds 20, but the resolution of the mass spectrometer at those ranges is not sufficient to allow confident composition assignment. The fraction of mass concentration in the particle phase that is unassigned is $<10 \%$.

We utilized non-negative matrix factorization (NNMF) built into the MATLAB computing software (Berry et al., 2007) to determine what the general diurnal behaviors were during BAECC and to which each of the 1018 organic species comprising the gas and particle phases belonged. NNMF is analogous to positive matrix factorization (PMF), in that it explicitly describes the variability of the input data matrix with a reduced number of factors (Paatero and Tapper, 1994) to yield non-negative solutions. Yan et al. (2016) demonstrated the utility of the PMF technique on measurements of ELVOC measured by APiTOF CIMS (Junninen et al., 2010). The goals of the NNMF technique are similar, that is, to determine the type and number of groups that behave uniquely in time. One distinction is that the uncertainties associated with each of the input observations are currently not utilized by the NNMF approach as opposed to PMF. NNMF was performed separately for the organic species in the gas phase from those in the particle phase.
First, the hourly medians of the deviation from the daily mean for each of the 1018 organic species in the gas phase and the particle phase were determined, which effectively imparts equal weight to all species. Then, for each phase, NNMF was implemented on the $24(m) \times 1081(n)$ matrix with up to $23(n-1)$ factors yielding 23 diel trends $(W)$ and their corresponding weights $(H)$, or the degree to which each of the 1081 vectors belonged to the 23 trends. Not all 23 trends were statistically unique from one another or represented real atmospheric behavior, given that NNMF attempts to explicitly solve for the variability of the input matrix with an $n-1$ set of products of the trends $(W)$ and weights $(H)$. (More weight is given by NNMF to input vectors of greater magnitude, but since the input matrix here is the deviation from the daily mean, each species is given more or less equal weight.) That is to say, NNMF does not distinguish between signal and artifact or noise. To do so, we incrementally lowered the factor number $(n-1)$ of each NNMF computation until a satisfactory set of diel trends that were unique in terms of atmospheric behavior were determined. Each species was identified as belonging to not more than one trend, henceforth called subgroup, and exhibited a correlation coefficient $\left(R^{2}\right)$ with that subgroup of greater than 0.45 . Species that did not meet this criterion were designated into an "others" subgroup. The robustness of this approach is easily verified by visualizing the diel trends of the subset of the input distinguished by these identifiers. The species in the "others" subgroup typically exhibited little to weak diel trends, likely affected by noise due to low signal.

A result of such a conservative approach is that species exhibiting subtle differences in temporal trends may be lumped into a single subgroup. Our goal with the implementation of NNMF was to identify broadly distinct trends that explain the behaviors of the majority of organic species detected by the iodide-ionization method without pre-grouping based upon their molecular composition (carbon atom number, oxygen to carbon ratio, etc.). We do, however, distinguish between the organic carbon and organic nitrate groups as they are products of distinctly different oxidation schemes.

\section{Results}

\subsection{Overview of detected compounds}

A total of 1018 compounds possessing unique molecular compositions were identified during BAECC. The mixing ratio distribution in the gas phase generally decreased with increasing molecular weight, whereas in the particle phase, compounds of higher molecular weights comprised a greater fraction of the total mass (Fig. 1), consistent with the idea that species of higher molecular weight more readily condense than those of lower molecular weight. The effective, or mixing ratio-weighted, molecular weight of the gas phase was $144 \mathrm{~g} \mathrm{~mol}^{-1}$, whereas the effective molecular weight of 

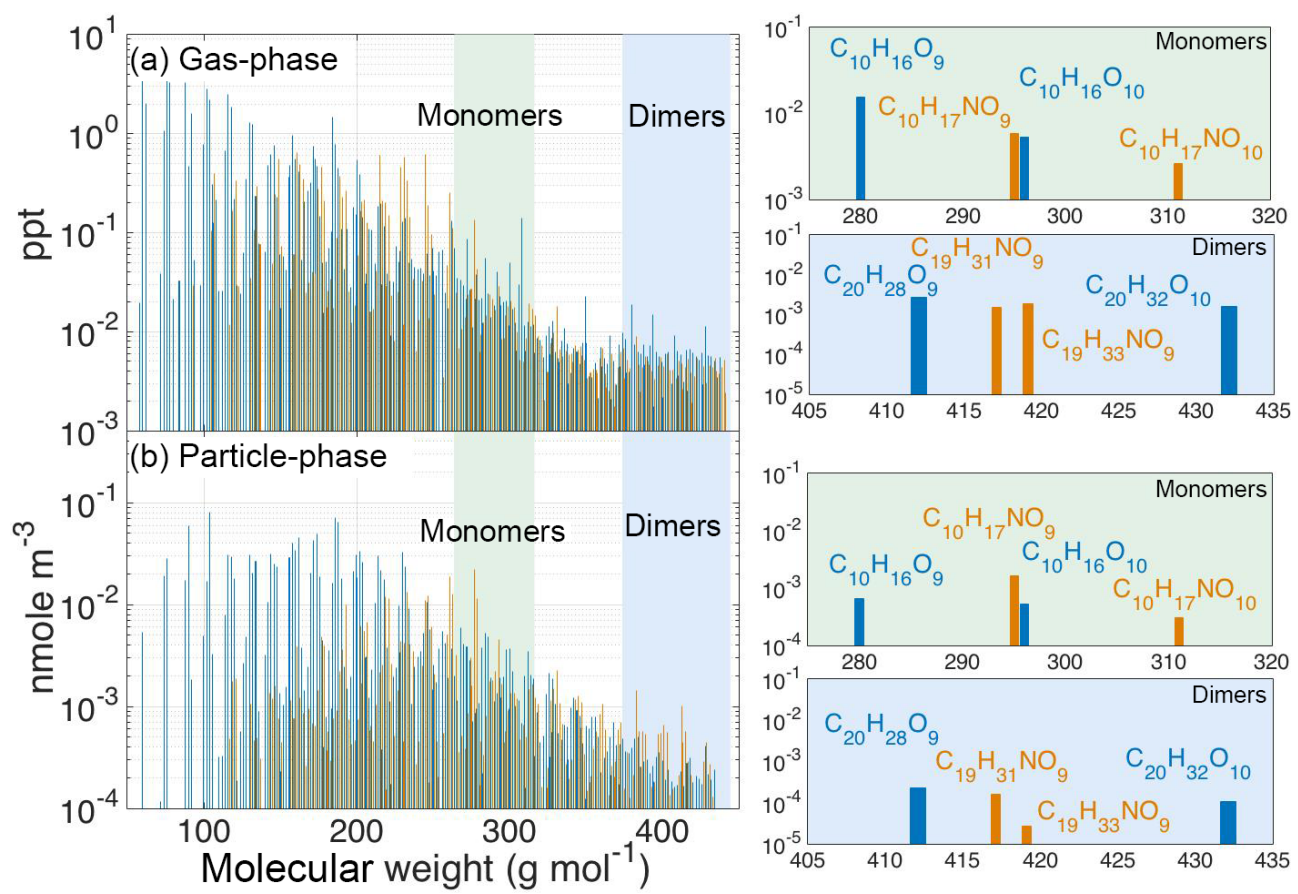

Figure 1. BAECC-median abundances of the organic nitrate (gold; $\mathrm{ON}=\mathrm{C}_{x} \mathrm{H}_{y} \mathrm{NO}_{z}$ ) and organic carbon (blue; $\mathrm{OC}=\mathrm{C}_{x} \mathrm{H}_{y} \mathrm{~N}_{0} \mathrm{O}_{z}$ ) species in the (a) gas and (b) particle phases, plotted as a function of their molecular weights. The shaded green and blue areas in (a) and (b) highlight the molecular weight ranges of monoterpene-derived HOM monomers $(\mathrm{nC}=10$ and $\mathrm{nO} \geq 7)$ and dimers $(\mathrm{nC} \geq 16)$. Sub-panels on the righthand side of (a) and (b) show the abundances of select monomers and dimers of the gas and particle phases, respectively.

the particle phase was $221 \mathrm{~g} \mathrm{~mol}^{-1}$. A number of relatively low molecular weight species $\left(<125 \mathrm{~g} \mathrm{~mol}^{-1}\right)$ were observed at levels greater than expected in the particle phase compared to those of higher molecular weights that, as a collective, typically exhibit an approximately bell-shaped distribution in abundance (Fig. 1). Those 50 species - accounting for on median $<7 \%$ of the total particulate organic mass as measured by the FIGAERO-CIMS - possibly originated from fragmentation of larger molecular weight compounds during thermal desorption (Lopez-Hilfiker et al., 2014). In the event that fragmentation of a large molecule during thermal desorption yielded multiple fragments that were not all detected by the FIGAERO-CIMS, this may explain why observations by the FIGAERO-CIMS were at minimum about half of the organic aerosol mass measured by an aerosol mass spectrometer (Lopez-Hilfiker et al., 2016b). The goal of this analysis given the suite of organic constituents measured is to determine their unique diel trends, which are unlikely to be driven by the effects of thermal fragmentation.

The FIGAERO-CIMS utilizing iodide-adduct ionization detected HOM monomers, defined here as those possessing 7 or more oxygen atoms, as well as dimers possessing at least 16 carbon atoms, with and without a nitrogen atom, in both the gas and particle phases (insets of Fig. 1a and b). The diel and day-to-day variability of their ambient concentrations were related to those of the ambient air temperature (Fig. 2), due likely to their being byproducts of monoterpene oxidation (since BVOC emission rates are dependent on ambient temperature), but also in part to the temperature dependence of the rate of autoxidation (Crounse et al., 2011), which presumably increases the yields of HOM species. The mixing ratios of HOM monomers and dimers observed above the forest canopy with iodide ionization were comparable to those observed at the same site in May to November of 2010 using the APi-TOF below the canopy (Ehn et al., 2012).

Approximately $90 \%$ of the detected gas-phase mass was comprised of organic compounds possessing 10 or less carbon atoms (insets in Fig. 3a and b). The abundance of species with 10 carbon atoms that comprised gaseous organic nitrates $\left(\mathrm{gON}=\mathrm{C}_{x} \mathrm{H}_{y} \mathrm{O}_{z} \mathrm{~N}_{1}\right)$ and organic carbon $\left(\mathrm{gOC}=\mathrm{C}_{x} \mathrm{H}_{y} \mathrm{O}_{z} \mathrm{~N}_{0}\right)$ decreased with increasing molecular weight (Fig. 3a and b), consistent with the general trend observed for all species in the gas phase (Fig. 1a). The decrease in abundance with increasing oxygen atom number was largely independent of carbon atom number, as summarized for the $\mathrm{C}_{1-7}, \mathrm{C}_{8-10}$, and $\mathrm{C}_{11-20}$ groups shown in the insets of Fig. 3a and b. This trend likely reflects the effects of decreasing volatility with additional attachment of an oxygen-containing functional group or accretion, and suggests that the yield of a given multifunctional organic compound from its presumed less-oxygenated precursor of the same carbon atom number is less than 0.5. Otherwise, the abundance distribution of species of a given $\mathrm{nC}$ would increase with every addition of an oxygen atom number $(\mathrm{nO})$. 


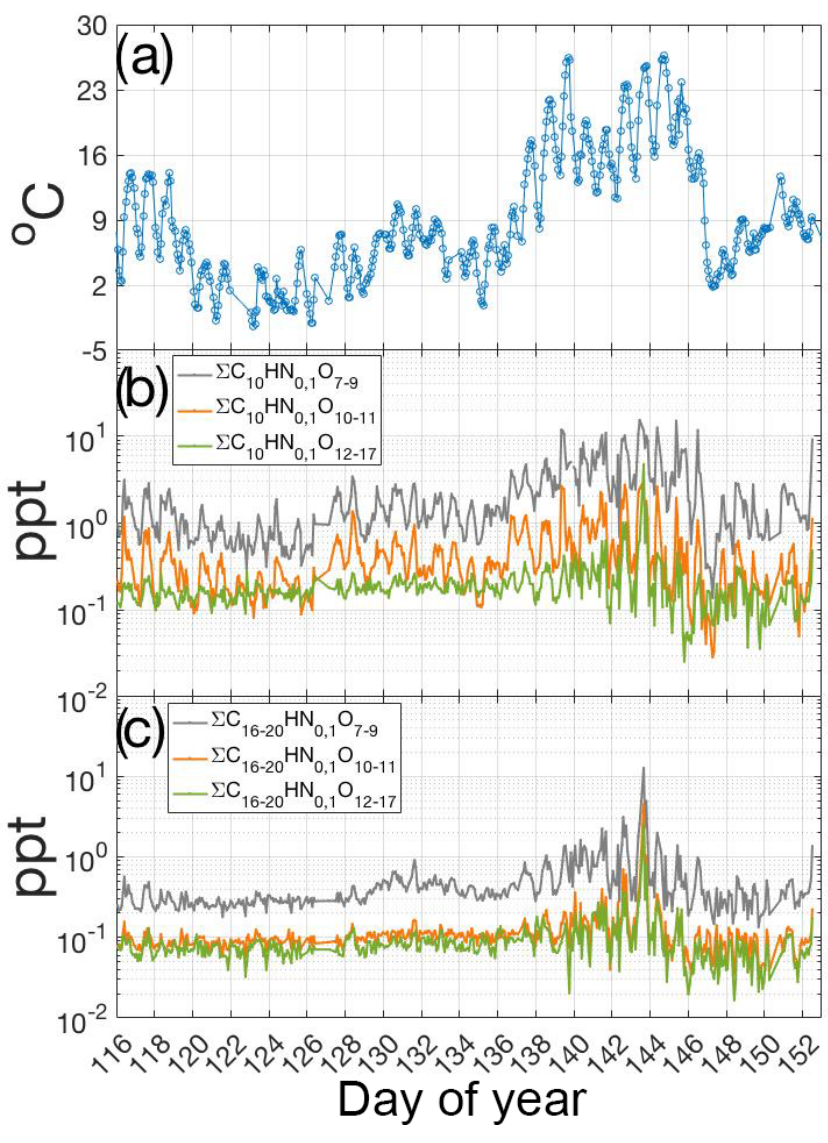

Figure 2. (a) Ambient temperature, (b) sum of the mixing ratios of three groups of gas-phase HOM monomers with varying ranges of oxygen atom number, and (c) sum of the mixing ratios of three groups of gas-phase HOM dimers with varying ranges of oxygen atom number, all observed during the BAECC campaign in the year 2014. Measurements of (b) and (c) were made with the FIGAEROCIMS utilizing iodide-adduct ionization.

The detected particle-phase mass was mostly $(\sim 82 \%)$ in compounds possessing 10 or fewer carbon atoms (insets of Fig. $3 \mathrm{c}$ and d). In contrast to the gas phase, however, the mass contribution from compounds with a higher oxygen atom number was greater with increasing carbon atom number (insets of Fig. $3 \mathrm{c}$ and d). This effect was more pronounced for particulate organic carbon $\left(\mathrm{pOC}=\mathrm{C}_{x} \mathrm{H}_{y} \mathrm{O}_{z} \mathrm{~N}_{0}\right)$ than it was for particulate organic nitrates $\left(\mathrm{pON}=\mathrm{C}_{x} \mathrm{H}_{y} \mathrm{O}_{z} \mathrm{~N}_{1}\right)$. Species that comprised $\mathrm{pON}$ and $\mathrm{pOC}$ within a given $\mathrm{nC}$ group generally exhibited an approximately bell-shaped distribution as a function of molecular weight, with those possessing five to eight oxygen atoms representing the apex within each $\mathrm{nC}$ group (Fig. 3c and d), consistent with observations from a mixed-deciduous forest in the southeastern US (Lee et al., 2016). The bell-shaped distribution of oxygen number for a given $\mathrm{nC}$ group observed in the particle phase is consistent with the decaying abundance of gas-phase species with oxygen number and the increasing thermodynamic driving force for such compounds to partition to the condensed phase. This notion assumes that the oxygen addition to hydrocarbon precursors occurs in the gas phase. Gaseous and particulate organic carbon compounds (gOC and pOC) with 11 to 20 carbon atoms (insets of Fig. $3 \mathrm{~b}$ and d) exhibited two modes with respect to oxygen atom number, where there was a noticeable decrease in abundance of those possessing 7 oxygen atoms compared to those with 4-6 and 8-10. This may have been due to the combined effects of auto-oxidation leading to additions of $\mathrm{O}_{2}$ following $\mathrm{OH}$ or $\mathrm{O}_{3}$ initiated oxidation of the parent $\mathrm{BVOC}$ and $\mathrm{RO}_{2}-\mathrm{RO}_{2}$ reactions that did not favor the formation of $\mathrm{C}_{11-20}$ dimer compounds with seven oxygen atoms.

\subsection{Diel trends: gas phase}

The complex and congested array of products present in both phases (Fig. 1) motivates the use of factorization techniques to reduce observed spectra into a smaller set of co-varying components with similar attributes. We present results from NNMF analyses that categorize each of the gON, gOC, pON, and $\mathrm{pOC}$ groups into subgroups defined by their unique behavior in time. Resulting diel patterns and day-to-day variations in the relative importance of different subgroups can be connected to expected shifts in precursor emissions, oxidant type $\left(\mathrm{O}_{3}, \mathrm{OH}, \mathrm{NO}_{3}\right.$, etc.), peroxy radical fate (reaction with $\mathrm{HO}_{2}, \mathrm{RO}_{2}, \mathrm{NO}$, or isomerization), and meteorological conditions (ambient temperature, boundary layer height, extent of mixing between above- and below-forest canopy, etc.) that affect gas-particle partitioning and multiphase chemistry.

In the gas phase, a total of 714 out of the 1018 identified species belonged to one of the three subgroups characterized by their unique diel trends (Fig. 4), determined as described in the Methods section. One subgroup exhibited a diel trend in which the ambient levels were enhanced at midday, another in which the levels were enhanced in the morning hours, and another during nighttime, henceforth referred to as the daytime, morning, and nighttime subgroups. The names of these groups should not be interpreted as definitive assignment to the timing of their production, but rather the timing of their collective enhancements at the measurement location. For example, a set of compounds produced overnight in the nocturnal residual layer may not be observed at the top of the instrument tower until mid-morning at the break-up of the nocturnal boundary layer.

The daytime, morning, and nighttime subgroups, which are comprised of 602,92 , and 20 organic species, respectively, accounted for a median $78,8.7$, and $3.0 \%$, respectively, of the total measured gas-phase mixing ratio. The daytime subgroup exhibited the lowest effective molecular weight relative to the other two subgroups (Table 1), due possibly to $\mathrm{OH}$ oxidation in the presence of $\mathrm{NO}$ (Fig. S1 in the Supplement) that favors formation of alkoxy radicals and subsequently $\mathrm{C}-\mathrm{C}$ bond scission products over those yielding HOM species (Seinfeld and Pandis, 2016). The daytime 

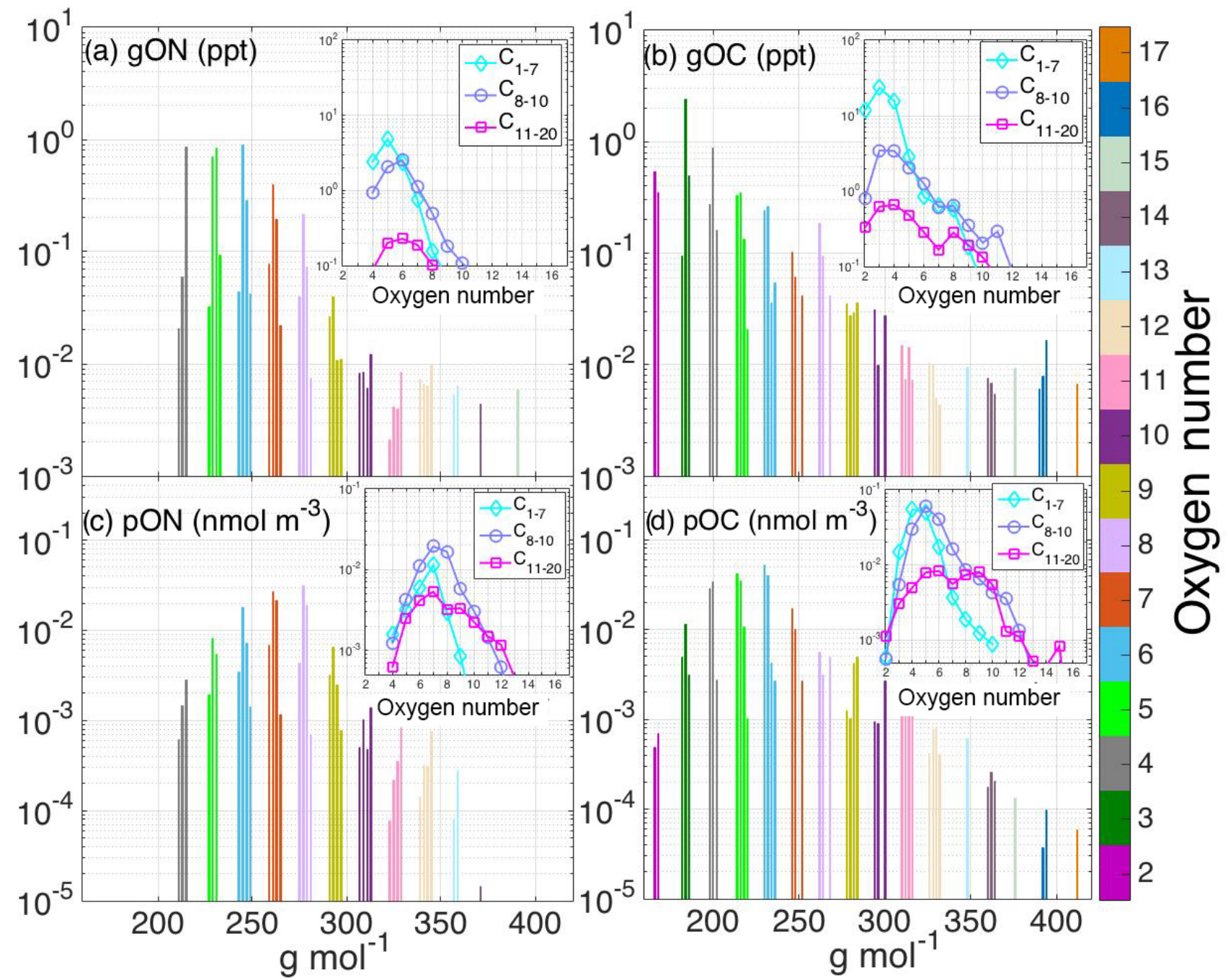

Figure 3. BAECC-median abundances of (a) gaseous ON, (b) gaseous OC, (c) particulate ON, and (d) particulate OC species possessing 10 carbon atoms, as a function of their molecular weights. Colors denote the oxygen atom number of each species. Gas-phase abundance generally decreased with increasing molecular weight, whereas the particle phase exhibited an approximate bell-shaped distribution in abundance. The insets in each panel show the campaign median abundances accounted for by species with 1 to 7,8 to 10 , and 11 to 20 carbon atoms, plotted as a function of their oxygen atom number.

diel trend is opposite that typically exhibited by monoterpene mixing ratios (Hakola et al., 2012), but consistent with that of their emission rate and levels of oxidants such as ozone $\left(\mathrm{O}_{3}\right)$ and the hydroxyl radical $(\mathrm{OH})$ (Spanke et al., 2001). Holzinger et al. (2005) also observed levels of BVOC oxidation products enhanced at daytime above the canopy at a monoterpene-emitting pine forest in California. Such trends imply that formation rates of these oxidation products were sufficiently higher during the day than night in order to overcome the lower parent BVOC concentrations and greater boundary layer height during the day, consistent with modeling results that were specific to the SMEAR II site (Smolander et al., 2014).

Semi-volatile and HOM organic species enhanced during the morning period were likely produced by chemistry fa- vored under conditions of lower $\mathrm{RO}_{2}$ : NO ratios than those at daytime, considering BVOC emission rates were weaker and $\mathrm{NO}$ levels were elevated due to photolysis of $\mathrm{NO}_{x}$ that had accumulated in the nocturnal surface layer (Horii et al., 2004; Min et al., 2014) (Fig. S1 in the Supplement). As such, the effective nitrogen atom number $(\mathrm{nN})$ of the morning gasphase subgroup was 0.5 ; that is, half of the number density was comprised of organic nitrates, a value higher than those exhibited by the day and night subgroups (Table 1). Entrainment of intra-canopy air and/or air above the nocturnal surface layer, not sampled at night due to slow mixing, may have also contributed to the morning subgroup.

Only 20 gaseous species (Fig. 4e), none classified as a HOM species, were elevated at night. Out of those 20, 9 were ON species that comprised on median about $20 \%$ of the 
Table 1. Effective molecular compositions, molecular weights, mixing ratio or mass concentration, and number of species belonging to the four subgroups (daytime, nighttime, morning, and others) of gas-phase organic nitrates $\left(\mathrm{gON}=\mathrm{C}_{x} \mathrm{H}_{y} \mathrm{NO}_{z}\right.$ ), gas-phase organic carbon $\left(\mathrm{gOC}=\mathrm{C}_{x} \mathrm{H}_{y} \mathrm{~N}_{0} \mathrm{O}_{z}\right)$, particulate organic nitrates (pON), and particulate organic carbon (pOC). Corresponding effective statistics for all gasphase products ( $\mathrm{gON}$ and $\mathrm{gOC}$ ) and particle-phase products (pON and $\mathrm{pOC}$ ) are also shown. The campaign-median mixing ratio of gOC is $62 \mathrm{ppt}$, which given its effective molecular weight of $121 \mathrm{~g} \mathrm{~mol}^{-1}$ is about $0.3 \mu \mathrm{g} \mathrm{m}^{-3}$.

\begin{tabular}{|c|c|c|c|c|}
\hline & Daytime & Nighttime & Morning & Others \\
\hline Gas phase & $\begin{array}{r}\mathrm{C}_{4.7} \mathrm{H}_{7.8} \mathrm{~N}_{0.1} \mathrm{O}_{4.0} \\
130 \mathrm{~g} \mathrm{~mol}^{-1} \\
71.8 \mathrm{ppt} \\
n=602\end{array}$ & $\begin{array}{r}\mathrm{C}_{9.2} \mathrm{H}_{14.9} \mathrm{~N}_{0.2} \mathrm{O}_{3.2} \\
181 \mathrm{~g} \mathrm{~mol}^{-1} \\
3.1 \mathrm{ppt} \\
n=20\end{array}$ & $\begin{array}{r}\mathrm{C}_{7.5} \mathrm{H}_{11.7} \mathrm{~N}_{0.5} \mathrm{O}_{4.9} \\
196 \mathrm{~g} \mathrm{~mol}^{-1} \\
8.9 \mathrm{ppt} \\
n=92\end{array}$ & $\begin{array}{r}\mathrm{C}_{8.8} \mathrm{H}_{14.4} \mathrm{~N}_{0.5} \mathrm{O}_{4.9} \\
204 \mathrm{~g} \mathrm{~mol}^{-1} \\
9.6 \mathrm{ppt} \\
n=304\end{array}$ \\
\hline gOC & $\begin{array}{r}\mathrm{C}_{4.5} \mathrm{H}_{7.5} \mathrm{O}_{3.7} \\
121 \mathrm{~g} \mathrm{~mol}^{-1} \\
62 \mathrm{ppt} \\
n=392\end{array}$ & $\begin{array}{r}\mathrm{C}_{9.1} \mathrm{H}_{14.7} \mathrm{O}_{2.8} \\
169 \mathrm{~g} \mathrm{~mol}^{-1} \\
2.5 \mathrm{ppt} \\
n=11\end{array}$ & $\begin{array}{r}\mathrm{C}_{7.2 \mathrm{H}_{11.2} \mathrm{O}_{4.2}} \\
182 \mathrm{~g} \mathrm{~mol}^{-1} \\
4.0 \mathrm{ppt} \\
n=33\end{array}$ & $\begin{array}{r}\mathrm{C}_{8.5} \mathrm{H}_{14.4} \mathrm{O}_{4.1} \\
181 \mathrm{~g} \mathrm{~mol}^{-1} \\
5.1 \mathrm{ppt} \\
n=148\end{array}$ \\
\hline gON & $\begin{array}{r}\mathrm{C}_{5.8} \mathrm{H}_{9.8} \mathrm{NO}_{5.7} \\
184 \mathrm{~g} \mathrm{~mol}^{-1} \\
9.4 \mathrm{ppt} \\
n=210\end{array}$ & $\begin{array}{r}\mathrm{C}_{9.6} \mathrm{H}_{15.7} \mathrm{NO}_{5.1} \\
227 \mathrm{~g} \mathrm{~mol}^{-1} \\
0.6 \mathrm{ppt} \\
n=9\end{array}$ & $\begin{array}{r}\mathrm{C}_{7.8} \mathrm{H}_{12.1} \mathrm{NO}_{5.6} \\
209 \mathrm{~g} \mathrm{~mol}^{-1} \\
4.9 \mathrm{ppt} \\
n=59\end{array}$ & $\begin{array}{r}\mathrm{C}_{9.3} \mathrm{H}_{14.5} \mathrm{NO}_{5.8} \\
232 \mathrm{~g} \mathrm{~mol}^{-1} \\
4.5 \mathrm{ppt} \\
n=156\end{array}$ \\
\hline Particle phase & $\begin{array}{r}\mathrm{C}_{8.5} \mathrm{H}_{12.8} \mathrm{~N}_{0.1} \mathrm{O}_{5.8} \\
212 \mathrm{~g} \mathrm{~mol}^{-1} \\
0.25 \mu \mathrm{g} \mathrm{m}^{-3} \\
n=519\end{array}$ & $\begin{array}{r}\mathrm{C}_{12.7} \mathrm{H}_{20.2} \mathrm{~N}_{0.9} \mathrm{O}_{7.9} \\
311 \mathrm{~g} \mathrm{~mol}^{-1} \\
0.031 \mu \mathrm{g} \mathrm{m}^{-3} \\
n=125\end{array}$ & $\begin{array}{r}\mathrm{C}_{8.9} \mathrm{H}_{13.5} \mathrm{~N}_{0.3} \mathrm{O}_{5.7} \\
216 \mathrm{~g} \mathrm{~mol}^{-1} \\
0.23 \mu \mathrm{g} \mathrm{m}^{-3} \\
n=332\end{array}$ & $\begin{array}{r}\mathrm{C}_{9.4} \mathrm{H}_{15.7} \mathrm{~N}_{0.1} \mathrm{O}_{6.1} \\
231 \mathrm{~g} \mathrm{~mol}^{-1} \\
4.0 \times 10^{-3} \mu \mathrm{g} \mathrm{m}^{-3} \\
n=42\end{array}$ \\
\hline pOC & $\begin{array}{r}\mathrm{C}_{8.6} \mathrm{H}_{13.1} \mathrm{O}_{5.8} \\
210 \mathrm{~g} \mathrm{~mol}^{-1} \\
0.23 \mu \mathrm{g} \mathrm{m}^{-3} \\
n=378\end{array}$ & $\begin{array}{r}\mathrm{C}_{16.8} \mathrm{H}_{29.2} \mathrm{O}_{12.2} \\
427 \mathrm{~g} \mathrm{~mol}^{-1} \\
3.0 \times 10^{-3} \mu \mathrm{g} \mathrm{m}^{-3} \\
n=28\end{array}$ & $\begin{array}{r}\mathrm{C}_{8.5} \mathrm{H}_{13.0} \mathrm{O}_{5.0} \\
196 \mathrm{~g} \mathrm{~mol}^{-1} \\
0.16 \mu \mathrm{g} \mathrm{m}^{-3} \\
n=151\end{array}$ & $\begin{array}{r}\mathrm{C}_{9.6} \mathrm{H}_{15.9} \mathrm{O}_{6.0} \\
231 \mathrm{~g} \mathrm{~mol}^{-1} \\
3.0 \times 10^{-3} \mu \mathrm{g} \mathrm{m}^{-3} \\
n=27\end{array}$ \\
\hline pON & $\begin{array}{r}\mathrm{C}_{7.4} \mathrm{H}_{11.0} \mathrm{NO}_{7.1} \\
227 \mathrm{~g} \mathrm{~mol}^{-1} \\
0.022 \mu \mathrm{g} \mathrm{m}^{-3} \\
n=141\end{array}$ & $\begin{array}{r}\mathrm{C}_{12.2} \mathrm{H}_{19.0} \mathrm{NO}_{7.3} \\
297 \mathrm{~g} \mathrm{~mol}^{-1} \\
0.028 \mu \mathrm{g} \mathrm{m}^{-3} \\
n=97\end{array}$ & $\begin{array}{r}\mathrm{C}_{9.9} \mathrm{H}_{14.8} \mathrm{NO}_{7.3} \\
264 \mathrm{~g} \mathrm{~mol}^{-1} \\
0.067 \mu \mathrm{g} \mathrm{m}^{-3} \\
n=181\end{array}$ & $\begin{array}{r}\mathrm{C}_{8.2} \mathrm{H}_{14.2} \mathrm{NO}_{6.3} \\
228 \mathrm{~g} \mathrm{~mol}^{-1} \\
1.0 \times 10^{-3} \mu \mathrm{g} \mathrm{m}^{-3} \\
n=15\end{array}$ \\
\hline
\end{tabular}

nighttime subgroup (effective $\mathrm{nN}=0.2$; see Table 1 ), even though levels of $\mathrm{NO}_{x}$ and monoterpenes are typically higher at night when $\mathrm{NO}_{3}$-initiated chemistry occurs. In the particle phase, however, 125 species, including many HOM species, exhibited nighttime enhancements (Fig. 5e). Out of those 125, 97 were organic nitrates (Table 1). The fact that species expressing one diel trend in the gas phase did not strictly follow the same diel trend in the particle phase suggests a process more complex than equilibrium-driven gas-particle partitioning for some compounds, possibly multiphase chemistry. The remaining 360 out of the total 1018 species in the gas phase did not exhibit strong enough diel trends to qualify being categorized in any of the three subgroups due in part to their low abundance relative to the instrument detection limit. These remaining 360 species accounted for on median $9.8 \%$ of the total gas-phase mixing ratio.

The diel trends of the three gas-phase subgroups determined here are similar to those of the three factors obtained using positive matrix factorization by Yan et al. (2016), which report on measurements made at the same research site during spring/summer of 2012. The abundances accounted for by each subgroup, however, differ. The iodideionization technique above the forest canopy deployed during spring/summer of 2014 (and reported here) observed most gaseous species to belong to the daytime subgroup (Fig. 6c), whereas measurements near the canopy floor by nitrate ionization during spring/summer of 2012 observed nearly equal distribution amongst the three diel-sorted factors (Yan et al., 2016). And while molecules designated by Yan et al. (2016) as daytime "fingerprint" molecules such as $\mathrm{C}_{10} \mathrm{H}_{15} \mathrm{NO}_{8,11}, \mathrm{C}_{3} \mathrm{H}_{5} \mathrm{NO}_{6}, \mathrm{C}_{4} \mathrm{H}_{5} \mathrm{NO}_{7}, \mathrm{C}_{5} \mathrm{H}_{7} \mathrm{NO}_{7}$, $\mathrm{C}_{6} \mathrm{H}_{9} \mathrm{NO}_{7}$, and $\mathrm{C}_{7} \mathrm{H}_{9} \mathrm{NO}_{7}$ - were also observed above the forest canopy to exhibit daytime diel trends, two compounds designated by Yan et al. (2016) as nighttime "fingerprint" molecules - $\mathrm{C}_{10} \mathrm{H}_{14} \mathrm{O}_{7}$ and $\mathrm{C}_{10} \mathrm{H}_{14} \mathrm{O}_{9}$ - were observed above the forest canopy to exhibit daytime diel trends. The reason for the differing trends is unclear without conducting a side-by-side inter-comparison. But it is possible that iodideand nitrate-ionization methods detect distinct isomers that are governed by different chemistry, or that the vertical gra- 

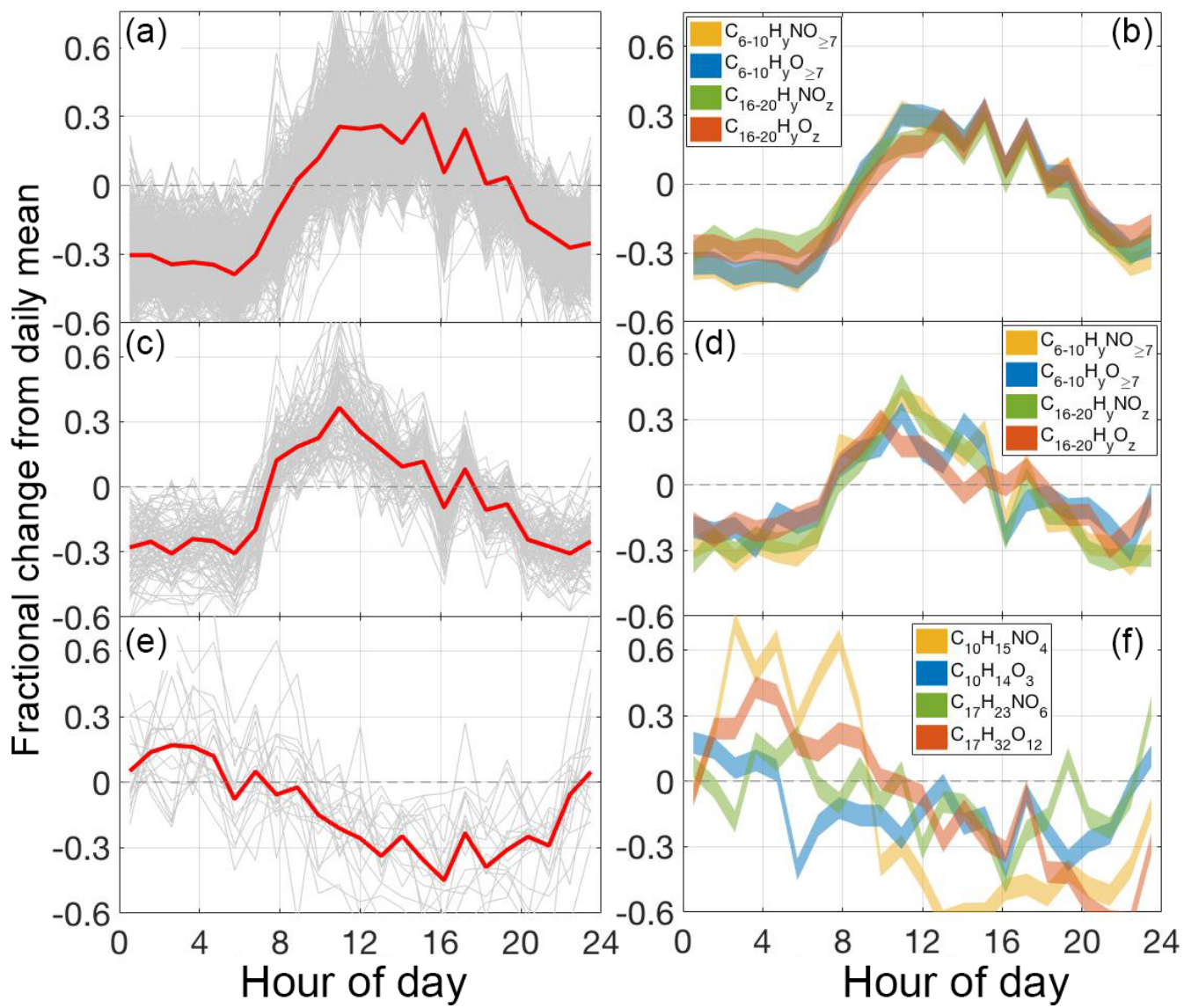

Figure 4. Fractional change from the daily mean of the organic gas-phase species belonging to the (a) daytime, (c) morning, and (e) nighttime subgroups, as categorized using non-negative matrix factorization. Red lines in (a), (c), and (e) represent the means of the species in that subgroup. (b), (d), and (f) show diel trends of all qualifying gON and gOC HOM monomers and dimers corresponding to the three subgroups shown in (a), (c), and (e), respectively. Individual species, as opposed to the mean of a collection of compounds, are shown for the (f) nighttime subgroup, as only 20 species exhibited a nighttime diel trend.

dients, particularly at night, confound comparison between measurements made above and below the forest canopy (Zha et al., 2017; Schobesberger et al., 2016).

The contributions of each of the subgroups to the total gas-phase mixing ratio exhibit distinct diel trends (Fig. 6), clearly reflecting the evolution on the timescale of hours of the chemical processes that govern air mass composition. The gOC group was dominated by the daytime subgroup (Fig. 6c), whereas the gON group experienced a greater contribution from the morning and nighttime subgroups (Fig. 6a). The contribution of each subgroup to the total, outside of the time period of its maximum enhancement, does not go to zero (Fig. 6). This suggests either the chemistry responsible for a given subgroup continues but is slower throughout the rest of the day and/or the products have lifetimes that are sufficiently long that they are still present after the chemistry responsible for their formation has diminished in a relative sense.

\subsection{Diel trends: particle phase}

A total of 976 out of the 1018 identified species that were detected in the particle phase belonged to one of the three subgroups as characterized by their diel trends (Fig. 5). The daytime, morning, and nighttime subgroups were comprised of 519,332 , and 125 organic compounds, respectively, and accounted for a median 51,43 , and $5.3 \%$, respectively, of the total particle-phase mass concentration (Table 1). The relative abundance for each of the three subgroups of the particle phase exhibited a bell-shaped distribution, while that of the three subgroups of the gas phase generally decreased with molecular weight (Fig. 7), as was similarly observed for $\mathrm{C}_{10}$ species (Fig. 3) and for all species as a collective (Fig. 1). The nighttime subgroup of the particle phase had the highest effective molecular weight, followed by the morning and daytime subgroups (Fig. 7). The nighttime subgroup of the particle phase exhibited the greatest effective $\mathrm{nN}(=0.9)$; that is, $90 \%$ of the particle mass was constituted by organic nitrates, whereas it was the morning subgroup of the gas phase that 

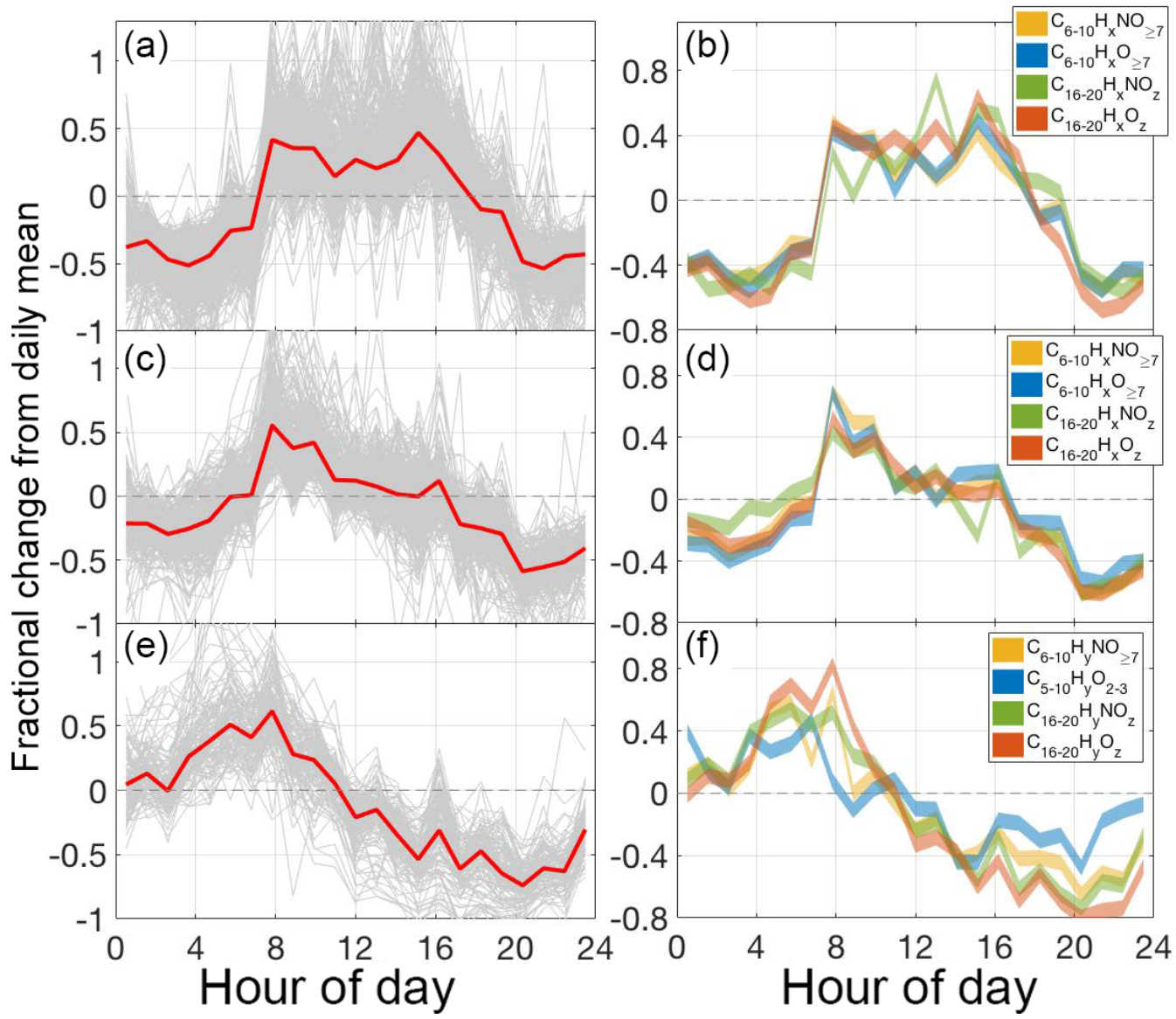

Figure 5. Same as Fig. 4, but for the particle phase. The nighttime subgroup of the particle phase was dominated by ON species. Only four OC compounds with 10 or less carbon atoms exhibited a nighttime diel trend and all possess 3 or less oxygen atoms, as shown (f) in blue.

exhibited the greatest $\mathrm{nN}(=0.5)$, as shown in Table 1. Additionally, pON was on median comprised roughly in equal parts by the three subgroups, whereas gON was dominated by the daytime subgroup with some contribution from the morning subgroup (Fig. 6b). A similar set of disparities in the contributions from the various subgroups of gOC (Fig. 6c) versus those of pOC (Fig. 6d) was also apparent. These observations, as noted above, also highlight the complexity of the relationship that likely exists between the organic constituents of the gas and particle phases.

Total organic aerosol and total nitrate mass loadings were measured from below the forest canopy using an aerosol mass spectrometer (DeCarlo et al., 2006; Dunlea et al., 2009). There was good agreement (slope $=1.09, R^{2}=0.37$ ) in pON measured by the two techniques, assuming that all of the particle-phase nitrate mass measured by the AMS was due to organic nitrates, and applying an average molecular weight of $265 \mathrm{~g} \mathrm{~mol}^{-1}$ (effective molecular weight of pON as measured by FIGAERO-CIMS) to the AMS nitrates (Fig. 8b). The pON measured by the two instruments exhibited similar diel trends, with the maxima reached in the early morning hours near sunrise. For total organic aerosol, the FIGAERO-CIMS detected approximately half of that observed by the AMS (slope $=0.66, R^{2}=0.23$ ), similar to previous comparisons between the two techniques (Lopez-Hilfiker et al., 2016b) (Fig. S2 in the Supplement). The diel trends exhibited by AMS organics and FIGAEROCIMS pON+pOC, however, showed markedly different diel trends (Fig. S2 in the Supplement), with the AMS exhibiting higher enhancement at night compared to day, whereas the FIGAERO-CIMS showed the opposite trend. The reason for the discrepancy may be that continued production of organic aerosol in the air mass below the nighttime forest canopy measured by the AMS is not seen by the FIGAERO-CIMS, due either to lack of mixing between above and below the canopy or that production of organic material by nighttime chemistry was not detectable by iodide ionization.

Lastly, we observed large variability (on the order of 20 to $30 \%$ ) in the contribution from each of the subgroups that comprised the total particulate organic mass (Fig. 6b and d). This variability occurred on the timescale of hours driven by the trends in the ambient abundances of each of the subgroups (Fig. 5). If the diel variability in the ambient abundances of each of the subgroups was driven by their chemi- 

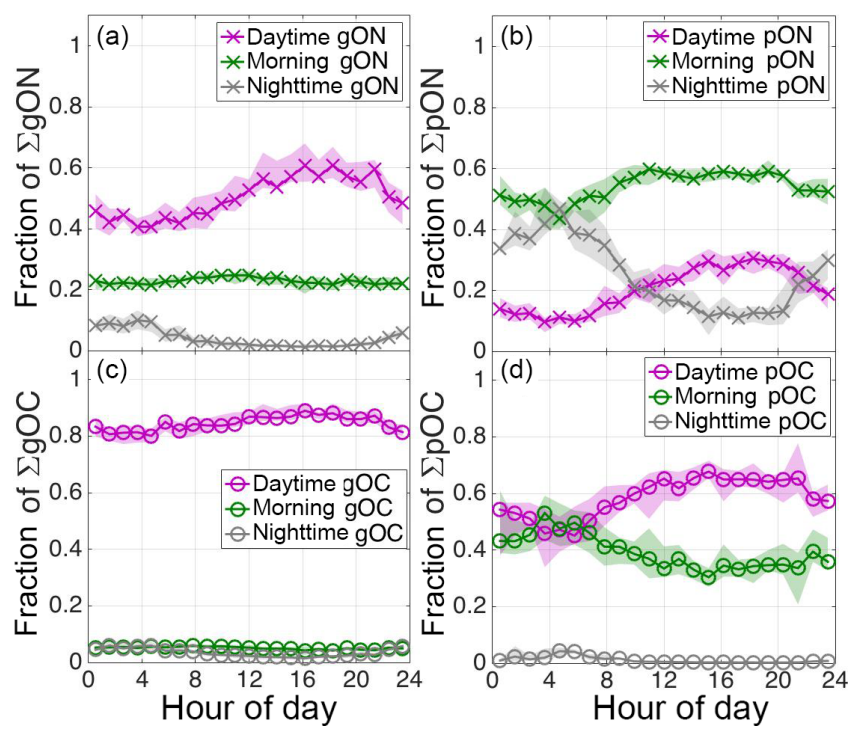

Figure 6. Mass fractions accounted for by the (purple) daytime, (green) morning, and (grey) nighttime subgroups in each of the (a) gON, (b) pON, (c) gOC, and (d) pOC groups, as a function of hour of day. The shaded regions represent the 25 th and 75 th quantiles.

cal production cycles (as reflected in the gas phase (Fig. 4), with which it is presumably in or close to equilibrium) as opposed to transport (that is, contribution of aerosols with different chemical compositions being advected to the site from elsewhere), the observed diel variability in the contribution from each of the subgroups (Fig. $6 \mathrm{~b}$ and d) suggests a rapid turnover in the material that comprises the particulate organic mass. That is, the organic material formed at a given time during the day must be lost on comparable timescales; otherwise, the mass fraction it contributes to the total would not change significantly throughout the time of day due to accumulation in the particle phase. For instance, we assume two compounds are produced on average at the same rate over the course of a model day, but that their production rates exhibit opposite diel trends, as shown in Fig. S3a in the Supplement. Their abundances are dictated by the balance between production and loss, as shown in Eqs. (1) and (2):

$$
\begin{aligned}
& \frac{\mathrm{d} A}{\mathrm{~d} t}=P_{A}-\frac{A}{\tau_{A}}, \\
& \frac{\mathrm{d} B}{\mathrm{~d} t}=P_{B}-\frac{B}{\tau_{B}},
\end{aligned}
$$

where $P_{A}$ and $P_{B}$ are the production rates $\left(\mathrm{s}^{-1}\right)$ of $A$ and $B$, respectively, and $\tau_{A}$ and $\tau_{B}$ are the lifetimes $(s)$ of $A$ and $B$, respectively. In this case, the lifetimes are with respect to the particle-phase component of $A$ and $B$, and not their overall lifetime in the atmosphere. That is, net repartitioning from the particle phase into the gas phase due to dilution would be represented in the lifetimes used in Eqs. (1) and (2).
In this model framework, abundances of $A$ and $B$ eventually reach diurnally repeating steady states within approximately 5 model days. $A$ and $B$ are analogous to the subgroups defined from the observations above, and the ratio of $A$ (or $B$ ) to the sum $A+B$ is analogous to the mass fraction of one of the observational subgroups to the total, as shown in Fig. $6 \mathrm{~b}$ and d. We find that if $A$ and $B$ possess lifetimes on the order of a day or longer, then the amplitude and rate of variability in the contribution one to the sum of both, i.e., $A /(A+B)$, are muted compared to the observed relative variations of the subgroups (Fig. S3b and c in the Supplement). Therefore, a rapid loss or short residence time in the particle phase (on the timescale of hours) is one explanation for the observations highlighted in Fig. $6 \mathrm{~b}$ and d.

Lee et al. (2016) demonstrated that the distinct diel trends exhibited by $\mathrm{C}_{5}$ pON species (presumably derived from isoprene oxidation) and $\mathrm{C}_{10} \mathrm{pON}$ species (monoterpenederived) were observed due to their hours-long lifetimes in the particle phase. Observations during BAECC suggest the lifetime of all organic constituents of the particle phase, not just organic nitrates, may be shorter than previously thought. A model to attribute specific chemical reactions and lifetimes to each of the subgroups observed during BAECC requires detailed information on oxidants $\left(\mathrm{NO}_{3}, \mathrm{OH}\right.$, etc.), radicals $\left(\mathrm{RO}_{2}, \mathrm{HO}_{2}\right.$, etc.) and meteorological conditions (boundary layer height, chemical conditions above/below surface layer, etc.) that are beyond the scope of this overview paper.

\subsection{Organic nitrates}

The mass contribution of organic nitrates to the total organic aerosol mass $(=\mathrm{pON} /(\mathrm{pON}+\mathrm{pOC}))$ exhibited a clear and distinct diel trend, with a maximum of $\sim 0.35$ around sunrise and minimum $\sim 0.15$ at midday (Fig. $8 \mathrm{a}$ ). This was consistent with the trend observed with the same FIGAEROCIMS coupled package in the southeastern US (Lee et al., 2016). However, in that study the pON contribution to the total aerosol mass was much lower $(\sim 0.05)$, even though $\mathrm{NO}_{x}$ levels were typically higher in the summertime in Centreville, AL, particularly at nighttime (Fig. S4 of Lee et al., 2016). Observations at BAECC were also consistent with other observations of unexpectedly high contributions of particle-phase organic nitrates, particularly at nighttime, to the total organic aerosol mass in regions with moderate to low $\mathrm{NO}_{x}$ emissions observed utilizing a network of aerosol mass spectrometers by Kiendler-Scharr et al. (2016).

It is unclear why the contribution of pON to the total organic aerosol mass was greater above the more pristine (less $\mathrm{NO}_{x}$ ) boreal forest of Hyytiälä, Finland, compared to the more polluted (more $\mathrm{NO}_{x}$ ) mixed-deciduous forest of the southeastern US (Fig. S1 in the Supplement and Fig. S4 of Lee et al., 2016). In addition to $\mathrm{NO}_{x}$, other parameters including monoterpene levels and their speciation (Fig. S1 of Ayres et al., 2015, and Hakola et al., 2012) were different at the two sites. Kiendlar-Scharr et al. (2016) attributed the high 


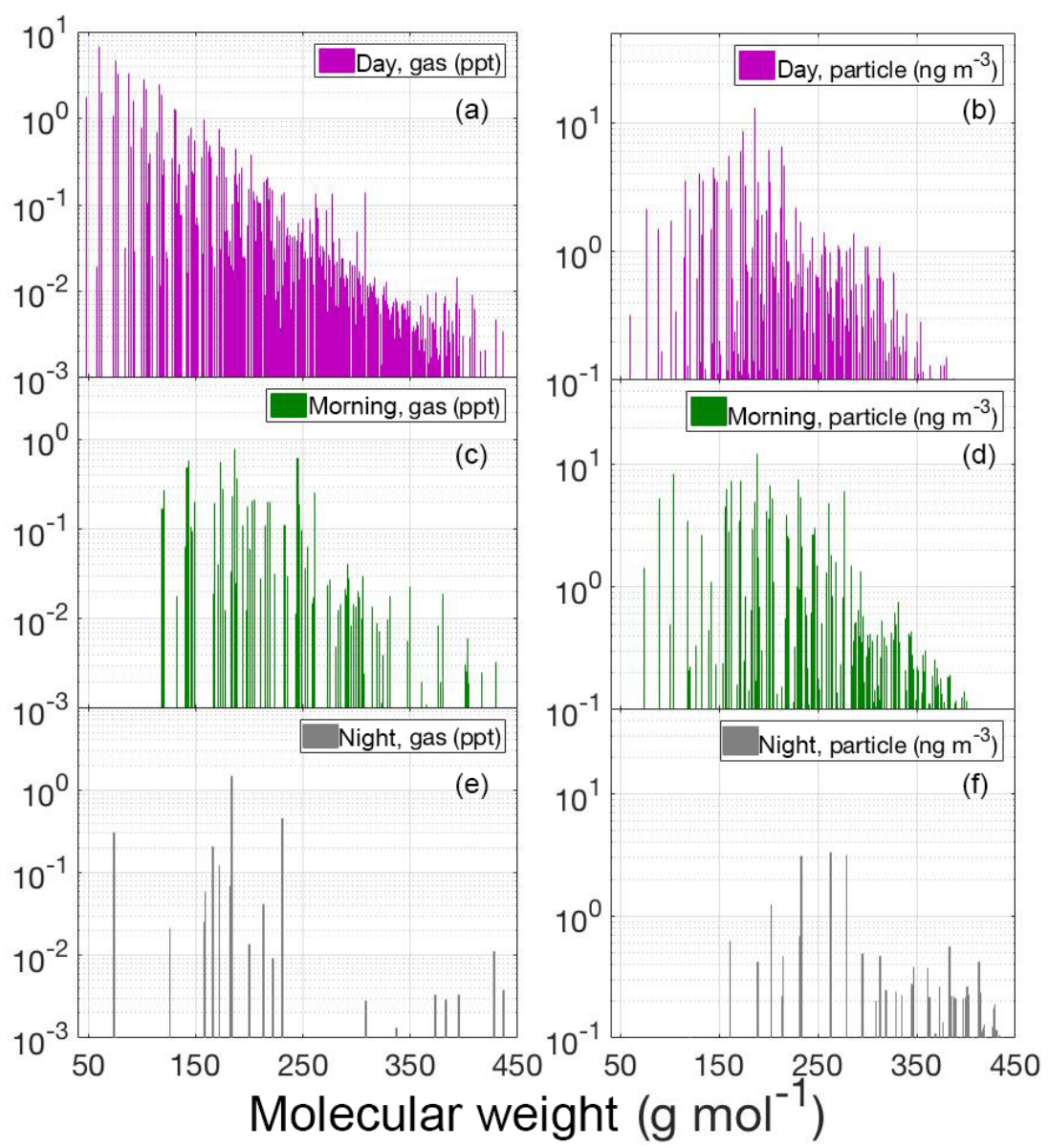

Figure 7. BAECC-median abundance distributions of the organic species comprising the (a, c, e) gas and (b, d, f) particle phases of the (a, b) daytime, $(\mathbf{c}, \mathbf{d})$ morning, and $(\mathbf{e}, \mathbf{f})$ nighttime subgroups, plotted as a function of their molecular weights.

contribution of $\mathrm{ON}$ to total $\mathrm{OA}$ to nighttime $\mathrm{NO}_{3}$-radicaldriven chemistry. However, gas-phase measurements during BAECC show only nine ON compounds exhibited a diel trend that would be consistent with $\mathrm{NO}_{3}$-driven chemistry (Liebmann et al., 2018) (Table 1), representing at most $10 \%$ of the total gON mixing ratio (Fig. 6a). The nighttime pON subgroup constituted at most $50 \%$ of the total pON mass in the few hours before sunrise, but its contribution dropped to about $10 \%$ at midday (Fig. 6b). We cannot rule out significant pON production by $\mathrm{NO}_{3}$ chemistry elsewhere, e.g., above the nocturnal surface layer in which the air mass would not be readily accessible to the FIGAERO-CIMS at the top of the tower in the stable nighttime atmosphere. But if faster chemical production of pON in the boreal forest was not the main reason why its contribution to total $\mathrm{OA}$ was greater, another possibility is that pON was lost faster relative to pOC in the mixed-deciduous forest with higher temperatures and absolute humidity.

Lastly, we observed ON species possessing 16 or more carbon atoms that belonged to all three subgroups of both the gas and particle phases, as shown in Figs. 4 and 5, respec- tively. These compositions are consistent with nitrate dimers of monoterpene oxidation products. The mass contribution of these nitrate dimers to total $\mathrm{pON}$ was significant, reaching an average maximum of $\sim 15 \%$ at nighttime and a minimum at daytime of $\sim 5 \%$ (Fig. 8a). While there are few, if any, reports of such nitrated dimers in both the gas and particle phases, there is evidence from offline analyses of particlephase SOA of nitrate oligomers (Nguyen et al., 2011). That we observed some of these dimers enhanced at night is suggestive of a possible role for $\mathrm{NO}_{3}$ radical chemistry. There continues to be debate as to the extent to which $\mathrm{NO}_{3}$-driven oxidation of $\sigma$-pinene contributes to SOA formation (Fry et al., 2014; Kurten et al., 2017). We propose here one way that $\mathrm{NO}_{3}$-radical-driven oxidation of $\sigma$-pinene could lead to SOA formation, namely through the reaction of the nitrate-derived peroxy radicals undergoing cross-reactions with other peroxy radicals, e.g., from ozonolysis or nighttime $\mathrm{OH}$ chemistry, to form low-volatility nitrated dimers (Fig. 9). This hypothesis is consistent with the observation of these dimers in the gas phase, and could be tested in a series of laboratory cham- 


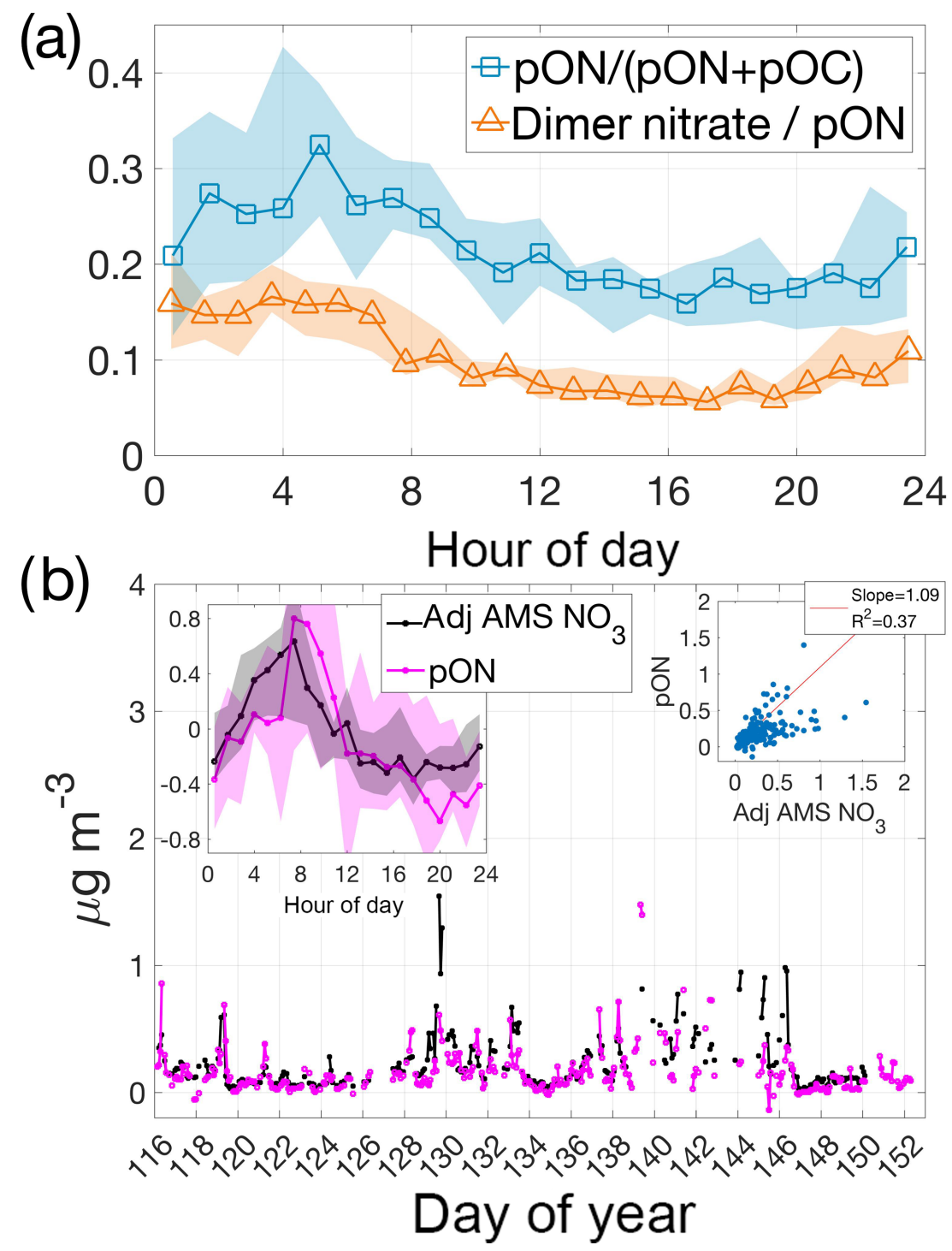

Figure 8. (a) Mass fraction of (blue) particulate organic nitrates to the total organic aerosol mass loading, both measured by the FIGAEROCIMS and mass fraction of (orange) dimer nitrates to the total organic nitrates, both measured by the FIGAERO-CIMS, as a function of hour of day. (b) Mass concentrations of (magenta) particulate organic nitrates measured by FIGAERO-CIMS and (black) total particle $\mathrm{NO}_{3}$ measured by HRToF-AMS but adjusted assuming all of the particle $\mathrm{NO}_{3}$ is composed of organic nitrates with an average molecular weight of $265 \mathrm{~g} \mathrm{~mol}^{-1}$ (i.e., assuming no contribution from inorganic nitrates such that adjusted $\mathrm{AMS} \mathrm{NO}_{3}=\mathrm{AMS} \mathrm{NO}_{3} \times 265 / 62$ ). Insets in $(\mathbf{b})$ show the comparison between $\mathrm{pON}$ and adjusted $\mathrm{AMS} \mathrm{NO}_{3}$, and the deviation from their daily respective means as a function of hour of day.

ber studies utilizing a FIGAERO-CIMS or similar technique capable of detecting such dimers.

\section{Conclusions}

Hourly measurements using the FIGAERO-CIMS of the abundance and molecular formulae provided a rich view of the organic constituents of the gas and particle phases above a boreal forest during the spring-summer transition season. Reduction of the observations using non-negative matrix factorization revealed that most species in both phases exhib- ited one of three distinct diel trends, one in which the ambient levels were enhanced at daytime, another during the early morning hours, and lastly at nighttime. The mass contribution of each subgroup, comprised of a unique set of compounds and defined by their distinct behavior in time, to the total particulate organic aerosol mass exhibited significant systematic diel variability that is broadly consistent with expectations of daytime photochemistry in the presence of $\mathrm{NO}$ and nighttime chemistry dominated by ozonolysis and $\mathrm{NO}_{3}$ chemistry together with diel boundary layer dynamics. Lastly, the contribution of organic nitrates to the total partic- 


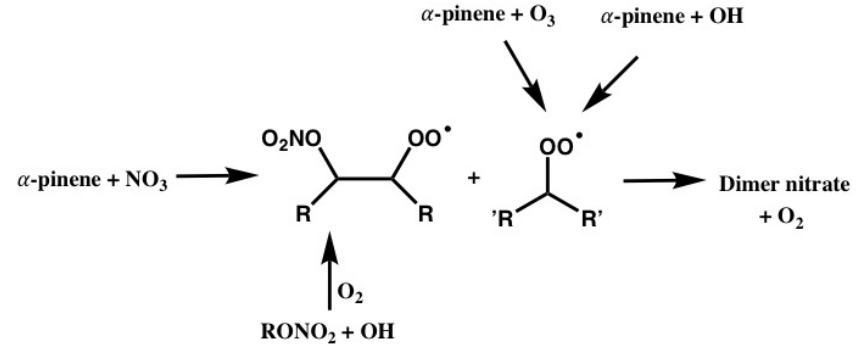

Figure 9. Schematic of the proposed chemical mechanism responsible for monoterpene dimer nitrates (those possessing 16 or more carbon atoms with a nitrate functional group) observed in the gas and particle phases during BAECC. The nitrated peroxy radical can be produced either by the $\mathrm{NO}_{3}$-radical oxidation of $\sigma$-pinene or by the $\mathrm{OH}$-radical oxidation of $\sigma$-pinene nitrate.

ulate organic mass exhibited a clear nighttime enhancement during BAECC, with a non-negligible contribution from nitrated dimer-like compounds, which may be formed by the reaction between a nitrated organic peroxy radical and nonnitrated peroxy radical. The mass fraction of pON to total OA observed by the same FIGAERO-CIMS was much lower at a temperate forest site in the southeastern US affected by higher nighttime levels of $\mathrm{NO}_{x}$. These observations suggest the rate of loss, more than the production, may have been a key difference between the two sites that determined the contribution of pON to the total organic aerosol burden.

Data availability. The FIGAERO-CIMS dataset encompassing all of the organic components of both the gas and particle phases, along with hourly time-dependent desorption profiles of each compound, for the entire 6-week duration of BAECC, is several gigabytes. As such, the group at the University of Washington will directly transfer the entire dataset or a version with some of the dimensions compressed by means most convenient to interested members of the community. Those who want access should contact the corresponding author, Joel Thornton, at thornton@atmos.uw.edu. Datasets of all other observations collected at the SMEAR sites can be accessed here (https://avaa.tdata.fi/web/smart/smear), while being mindful of the terms of use here (https://avaa.tdata.fi/web/smart/ smear/terms-of-use).

\section{The Supplement related to this article is available online at https://doi.org/10.5194/acp-18-11547-2018- supplement.}

Author contributions. BHL performed the analysis and wrote the paper. FDL deployed the instrument and processed the data. ELD facilitated instrument deployment and contributed insights including constructing Fig. 9. PZ, MB, TP, LH, and AV edited the paper. LH and AV contributed the AMS data. JAT funded the deployment, directed the analysis, and edited the paper.
Competing interests. The authors declare that they have no conflict of interest.

Acknowledgements. Funding support for the University of Washington was provided by the Department of Energy (DE-SC0006867 and DE-SC0018221). We acknowledge the support from the Academy of Finland Centre of Excellence (project no. 307331), Maj and Tor Nessling funding, the Nordic Centre of Excellence eSTICC (project no. 57001), and the Department of Energy support for AMF2 deployment during BAECC. The help of SMEAR II staff during the field study is gratefully acknowledged. The authors thank Petri I. R. Keronen for helpful suggestions and for contributing the $\mathrm{NO}_{x}$ and $\mathrm{O}_{3}$ observations.

Edited by: Delphine Farmer

Reviewed by: two anonymous referees

\section{References}

Ayres, B. R., Allen, H. M., Draper, D. C., Brown, S. S., Wild, R. J., Jimenez, J. L., Day, D. A., Campuzano-Jost, P., Hu, W., de Gouw, J., Koss, A., Cohen, R. C., Duffey, K. C., Romer, P., Baumann, K., Edgerton, E., Takahama, S., Thornton, J. A., Lee, B. H., Lopez-Hilfiker, F. D., Mohr, C., Wennberg, P. O., Nguyen, T. B., Teng, A., Goldstein, A. H., Olson, K., and Fry, J. L.: Organic nitrate aerosol formation via $\mathrm{NO}_{3}+$ biogenic volatile organic compounds in the southeastern United States, Atmos. Chem. Phys., 15, 13377-13392, https://doi.org/10.5194/acp-1513377-2015, 2015.

Berry, M. W., Browne, M., Langville, A. N., Pauca, V. P., and Plemmons, R. J.: Algorithms and applications for approximate nonnegative matrix factorization, Comput. Stat. Data An., 52, 155173, https://doi.org/10.1016/j.csda.2006.11.006, 2007.

Bianchi, F., Garmash, O., He, X., Yan, C., Iyer, S., Rosendahl, I., Xu, Z., Rissanen, M. P., Riva, M., Taipale, R., Sarnela, N., Petäjä, T., Worsnop, D. R., Kulmala, M., Ehn, M., and Junninen, H.: The role of highly oxygenated molecules (HOMs) in determining the composition of ambient ions in the boreal forest, Atmos. Chem. Phys., 17, 13819-13831, https://doi.org/10.5194/acp-17-138192017, 2017.

Bonan, G. B.: Forests and climate change: Forcings, feedbacks, and the climate benefits of forests, Science, 320, 1444-1449, https://doi.org/10.1126/science.1155121, 2008.

Crounse, J. D., Paulot, F., Kjaergaard, H. G., and Wennberg, P. O.: Peroxy radical isomerization in the oxidation of isoprene, Phys. Chem. Chem. Phys., 13, 13607-13613, https://doi.org/10.1039/c1cp21330j, 2011.

D’Ambro, E. L., Lee, B. H., Liu, J., Shilling, J. E., Gaston, C. J., Lopez-Hilfiker, F. D., Schobesberger, S., Zaveri, R. A., Mohr, C., Lutz, A., Zhang, Z., Gold, A., Surratt, J. D., Rivera-Rios, J. C., Keutsch, F. N., and Thornton, J. A.: Molecular composition and volatility of isoprene photochemical oxidation secondary organic aerosol under low- and high- $\mathrm{NO}_{x}$ conditions, Atmos. Chem. Phys., 17, 159-174, https://doi.org/10.5194/acp-17159-2017, 2017.

DeCarlo, P. F., Kimmel, J. R., Trimborn, A., Northway, M. J., Jayne, J. T., Aiken, A. C., Gonin, M., Fuhrer, 
K., Horvath, T., Docherty, K. S., Worsnop, D. R., and Jimenez, J. L.: Field-deployable, high-resolution, time-of-flight aerosol mass spectrometer, Anal. Chem., 78, 8281-8289, https://doi.org/10.1021/ac061249n, 2006.

Dunlea, E. J., DeCarlo, P. F., Aiken, A. C., Kimmel, J. R., Peltier, R. E., Weber, R. J., Tomlinson, J., Collins, D. R., Shinozuka, Y., McNaughton, C. S., Howell, S. G., Clarke, A. D., Emmons, L. K., Apel, E. C., Pfister, G. G., van Donkelaar, A., Martin, R. V., Millet, D. B., Heald, C. L., and Jimenez, J. L.: Evolution of Asian aerosols during transpacific transport in INTEX-B, Atmos. Chem. Phys., 9, 7257-7287, https://doi.org/10.5194/acp-9-72572009, 2009.

Ehn, M., Junninen, H., Petaja, T., Kurten, T., Kerminen, V. M., Schobesberger, S., Manninen, H. E., Ortega, I. K., Vehkamaki, H., Kulmala, M., and Worsnop, D. R.: Composition and temporal behavior of ambient ions in the boreal forest, Atmos. Chem. Phys., 10, 8513-8530, https://doi.org/10.5194/acp-108513-2010, 2010.

Ehn, M., Kleist, E., Junninen, H., Petaja, T., Lonn, G., Schobesberger, S., Dal Maso, M., Trimborn, A., Kulmala, M., Worsnop, D. R., Wahner, A., Wildt, J., and Mentel, T. F.: Gas phase formation of extremely oxidized pinene reaction products in chamber and ambient air, Atmos. Chem. Phys., 12, 5113-5127, https://doi.org/10.5194/acp-12-5113-2012, 2012.

Ehn, M., Thornton, J. A., Kleist, E., Sipila, M., Junninen, H., Pullinen, I., Springer, M., Rubach, F., Tillmann, R., Lee, B., LopezHilfiker, F., Andres, S., Acir, I. H., Rissanen, M., Jokinen, T., Schobesberger, S., Kangasluoma, J., Kontkanen, J., Nieminen, T., Kurten, T., Nielsen, L. B., Jorgensen, S., Kjaergaard, H. G., Canagaratna, M., Dal Maso, M., Berndt, T., Petaja, T., Wahner, A., Kerminen, V. M., Kulmala, M., Worsnop, D. R., Wildt, J., and Mentel, T. F.: A large source of low-volatility secondary organic aerosol, Nature, 506, 7489, https://doi.org/10.1038/nature13032, 2014.

Fry, J. L., Draper, D. C., Barsanti, K. C., Smith, J. N., Ortega, J., Winkle, P. M., Lawler, M. J., Brown, S. S., Edwards, P. M., Cohen, R. C., and Lee, L.: Secondary Organic Aerosol Formation and Organic Nitrate Yield from $\mathrm{NO}_{3}$ Oxidation of Biogenic Hydrocarbons, Environ. Sci. Technol., 48, 11944-11953, https://doi.org/10.1021/es502204x, 2014.

Goldstein, A. H. and Galbally, I. E.: Known and unexplored organic constituents in the earth's atmosphere, Environ. Sci. Technol., 41, 1514-1521, https://doi.org/10.1021/es072476p, 2007.

Guenther, A., Karl, T., Harley, P., Wiedinmyer, C., Palmer, P. I., and Geron, C.: Estimates of global terrestrial isoprene emissions using MEGAN (Model of Emissions of Gases and Aerosols from Nature), Atmos. Chem. Phys., 6, 3181-3210, https://doi.org/10.5194/acp-6-3181-2006, 2006.

Guenther, A. B., Jiang, X., Heald, C. L., Sakulyanontvittaya, T., Duhl, T., Emmons, L. K., and Wang, X.: The Model of Emissions of Gases and Aerosols from Nature version 2.1 (MEGAN2.1): an extended and updated framework for modeling biogenic emissions, Geosci. Model. Dev., 5, 1471-1492, https://doi.org/10.5194/gmd-5-1471-2012, 2012.

Hakola, H., Hellen, H., Hemmila, M., Rinne, J., and Kulmala, M.: In situ measurements of volatile organic compounds in a boreal forest, Atmos. Chem. Phys., 12, 11665-11678, https://doi.org/10.5194/acp-12-11665-2012, 2012.
Hallquist, M., Wenger, J. C., Baltensperger, U., Rudich, Y., Simpson, D., Claeys, M., Dommen, J., Donahue, N. M., George, C., Goldstein, A. H., Hamilton, J. F., Herrmann, H., Hoffmann, T., Iinuma, Y., Jang, M., Jenkin, M. E., Jimenez, J. L., KiendlerScharr, A., Maenhaut, W., McFiggans, G., Mentel, T. F., Monod, A., Prevot, A. S. H., Seinfeld, J. H., Surratt, J. D., Szmigielski, R., and Wildt, J.: The formation, properties and impact of secondary organic aerosol: current and emerging issues, Atmos. Chem. Phys., 9, 5155-5236, https://doi.org/10.5194/acp-9-51552009, 2009.

Hari, P. and Kulmala, M.: Station for measuring ecosystematmosphere relations (SMEAR II), Boreal Environ. Res., 10, 315-322, 2005.

Heald, C. L., Henze, D. K., Horowitz, L. W., Feddema, J., Lamarque, J. F., Guenther, A., Hess, P. G., Vitt, F., Seinfeld, J. H., Goldstein, A. H., and Fung, I.: Predicted change in global secondary organic aerosol concentrations in response to future climate, emissions, and land use change, J. Geophys. Res., 113, D05211, https://doi.org/10.1029/2007jd009092, 2008.

Holzinger, R., Lee, A., Paw, K. T., and Goldstein, A. H.: Observations of oxidation products above a forest imply biogenic emissions of very reactive compounds, Atmos. Chem. Phys., 5, 6775, https://doi.org/10.5194/acp-5-67-2005, 2005.

Horii, C. V., Munger, J. W., Wofsy, S. C., Zahniser, M., Nelson, D., and McManus, J. B.: Fluxes of nitrogen oxides over a temperate deciduous forest, J. Geophys. Res., 109, D08305, https://doi.org/10.1029/2003jd004326, 2004.

Hunter, J. F., Day, D. A., Palm, B. B., Yatavelli, R. L. N., Chan, A. H., Kaser, L., Cappellin, L., Hayes, P. L., Cross, E. S., Carrasquillo, A. J., Campuzano-Jost, P., Stark, H., Zhao, Y. L., Hohaus, T., Smith, J. N., Hansel, A., Karl, T., Goldstein, A. H., Guenther, A., Worsnop, D. R., Thornton, J. A., Heald, C. L., Jimenez, J. L., and Kroll, J. H.: Comprehensive characterization of atmospheric organic carbon at a forested site, Nat. Geosci., 10, 748-753, https://doi.org/10.1038/Ngeo3018, 2017.

Ilvesniemi, H. and Liu, C.: Biomass distribution in a young Scots pine stand, Boreal Environ. Res., 6, 3-8, 2001.

Isaacman-VanWertz, G., Massoli, P., O’Brien, R. E., Nowak, J. B., Canagaratna, M. R., Jayne, J. T., Worsnop, D. R., Su, L., Knopf, D. A., Misztal, P. K., Arata, C., Goldstein, A. H., and Kroll, J. H.: Using advanced mass spectrometry techniques to fully characterize atmospheric organic carbon: current capabilities and remaining gaps, Faraday Discuss., 200, 579-598, https://doi.org/10.1039/c7fd00021a, 2017.

Jimenez, J. L., Canagaratna, M. R., Donahue, N. M., Prevot, A. S. H., Zhang, Q., Kroll, J. H., DeCarlo, P. F., Allan, J. D., Coe, H., Ng, N. L., Aiken, A. C., Docherty, K. S., Ulbrich, I. M., Grieshop, A. P., Robinson, A. L., Duplissy, J., Smith, J. D., Wilson, K. R., Lanz, V. A., Hueglin, C., Sun, Y. L., Tian, J., Laaksonen, A., Raatikainen, T., Rautiainen, J., Vaattovaara, P., Ehn, M., Kulmala, M., Tomlinson, J. M., Collins, D. R., Cubison, M. J., Dunlea, E. J., Huffman, J. A., Onasch, T. B., Alfarra, M. R., Williams, P. I., Bower, K., Kondo, Y., Schneider, J., Drewnick, F., Borrmann, S., Weimer, S., Demerjian, K., Salcedo, D., Cottrell, L., Griffin, R., Takami, A., Miyoshi, T., Hatakeyama, S., Shimono, A., Sun, J. Y., Zhang, Y. M., Dzepina, K., Kimmel, J. R., Sueper, D., Jayne, J. T., Herndon, S. C., Trimborn, A. M., Williams, L. R., Wood, E. C., Middlebrook, A. M., Kolb, C. E., Baltensperger, U., and Worsnop, D. R.: Evolution of Or- 
ganic Aerosols in the Atmosphere, Science, 326, 1525-1529, https://doi.org/10.1126/science.1180353, 2009.

Junninen, H., Lauri, A., Keronen, P., Aalto, P., Hiltunen, V., Hari, P., and Kulmala, M.: Smart-SMEAR: on-line data exploration and visualization tool for SMEAR stations, Boreal Environ. Res., 14, 447-457, 2009.

Junninen, H., Ehn, M., Petaja, T., Luosujarvi, L., Kotiaho, T., Kostiainen, R., Rohner, U., Gonin, M., Fuhrer, K., Kulmala, M., and Worsnop, D. R.: A high-resolution mass spectrometer to measure atmospheric ion composition, Atmos. Meas. Tech., 3, 10391053, https://doi.org/10.5194/amt-3-1039-2010, 2010.

Kavouras, I. G., Mihalopoulos, N., and Stephanou, E. G.: Formation of atmospheric particles from organic acids produced by forests, Nature, 395, 683-686, https://doi.org/10.1038/27179, 1998.

Kiendler-Scharr, A., Mensah, A. A., Friese, E., Topping, D., Nemitz, E., Prevot, A. S. H., Aijala, M., Allan, J., Canonaco, F., Canagaratna, M., Carbone, S., Crippa, M., Dall Osto, M., Day, D. A., De Carlo, P., Di Marco, C. F., Elbern, H., Eriksson, A., Freney, E., Hao, L., Herrmann, H., Hildebrandt, L., Hillamo, R., Jimenez, J. L., Laaksonen, A., McFiggans, G., Mohr, C., O’Dowd, C., Otjes, R., Ovadnevaite, J., Pandis, S. N., Poulain, L., Schlag, P., Sellegri, K., Swietlicki, E., Tiitta, P., Vermeulen, A., Wahner, A., Worsnop, D., and Wu, H. C.: Ubiquity of organic nitrates from nighttime chemistry in the European submicron aerosol, Geophys. Res. Lett., 43, 7735-7744, https://doi.org/10.1002/2016GL069239, 2016.

Kroll, J. H., Donahue, N. M., Jimenez, J. L., Kessler, S. H., Canagaratna, M. R., Wilson, K. R., Altieri, K. E., Mazzoleni, L. R., Wozniak, A. S., Bluhm, H., Mysak, E. R., Smith, J. D., Kolb, C. E., and Worsnop, D. R.: Carbon oxidation state as a metric for describing the chemistry of atmospheric organic aerosol, Nat. Chem., 3, 133-139, https://doi.org/10.1038/Nchem.948, 2011.

Kulmala, M. Rannik, Ü, Pirjola, L., Dal Maso, M. Karimäki, J., Asmi, A., Jäppinen, A., Karhu, V., Korhonen, H., Malvikko, S.P., Puustinen, A., Raittila, J., Romakkaniemi, S., Suni, T., YliKoivisto, S., Paatero, J. Hari, P., and Vesala, T.: Characterization of atmospheric trace gas and aerosol concentrations at forest sites in southern and northern Finland using back trajectories, Boreal Environ. Res., 5, 315-336, 2000

Kulmala, M., Hameri, K., Aalto, P. P., Makela, J. M., Pirjola, L., Nilsson, E. D., Buzorius, G., Rannik, U., Dal Maso, M., Seidl, W., Hoffman, T., Janson, R., Hansson, H. C., Viisanen, Y., Laaksonen, A., and O'Dowd, C. D.: Overview of the international project on biogenic aerosol formation in the boreal forest (BIOFOR), Tellus B, 53, 324-343, https://doi.org/10.1034/j.16000889.2001.530402.x, 2001.

Kurten, T., Moller, K. H., Nguyen, T. B., Schwantes, R. H., Misztal, P. K., Su, L. P., Wennberg, P. O., Fry, J. L., and Kjaergaard, H. G.: Alkoxy Radical Bond Scissions Explain the Anomalously Low Secondary Organic Aerosol and Organonitrate Yields From alpha-Pinene $+\mathrm{NO}_{3}$, J. Phys. Chem. Lett., 8, 2826-2834, https://doi.org/10.1021/acs.jpclett.7b01038, 2017.

Lee, B. H., Lopez-Hilfiker, F. D., Mohr, C., Kurten, T., Worsnop, D. R., and Thornton, J. A.: An Iodide-Adduct HighResolution Time-of-Flight Chemical-Ionization Mass Spectrometer: Application to Atmospheric Inorganic and Organic Compounds, Environ. Sci. Technol., 48, 6309-6317, https://doi.org/10.1021/es500362a, 2014.
Lee, B. H., Mohr, C., Lopez-Hilfiker, F. D., Lutz, A., Hallquist, M., Lee, L., Romer, P., Cohen, R. C., Iyer, S., Kurten, T., Hu, W. W., Day, D. A., Campuzano-Jost, P., Jimenez, J. L., Xu, L., Ng, N. L., Guo, H. Y., Weber, R. J., Wild, R. J., Brown, S. S., Koss, A., de Gouw, J., Olson, K., Goldstein, A. H., Seco, R., Kim, S., McAvey, K., Shepson, P. B., Starn, T., Baumann, K., Edgerton, E. S., Liu, J. M., Shilling, J. E., Miller, D. O., Brune, W., Schobesberger, S., D'Ambro, E. L., and Thornton, J. A.: Highly functionalized organic nitrates in the southeast United States: Contribution to secondary organic aerosol and reactive nitrogen budgets, P. Natl. Acad. Sci. USA, 113, 1516-1521, https://doi.org/10.1073/pnas.1508108113, 2016.

Liebmann, J., Karu, E., Sobanski, N., Schuladen, J., Ehn, M., Schallhart, S., Quéléver, L., Hellen, H., Hakola, H., Hoffmann, T., Williams, J., Fischer, H., Lelieveld, J., and Crowley, J. N.: Direct measurement of $\mathrm{NO}_{3}$ radical reactivity in a boreal forest, Atmos. Chem. Phys., 18, 3799-3815, https://doi.org/10.5194/acp18-3799-2018, 2018.

Liu, J. M., D’Ambro, E. L., Lee, B. H., Lopez-Hilfiker, F. D., Zaveri, R. A., Rivera-Rios, J. C., Keutsch, F. N., Iyer, S., Kurten, T., Zhang, Z. F., Gold, A., Surratt, J. D., Shilling, J. E., and Thornton, J. A.: Efficient Isoprene Secondary Organic Aerosol Formation from a Non-IEPDX Pathway, Environ. Sci. Technol., 50, 9872-9880, https://doi.org/10.1021/acs.est.6b01872, 2016.

Lopez-Hilfiker, F. D., Mohr, C., Ehn, M., Rubach, F., Kleist, E., Wildt, J., Mentel, T. F., Lutz, A., Hallquist, M., Worsnop, D., and Thornton, J. A.: A novel method for online analysis of gas and particle composition: description and evaluation of a Filter Inlet for Gases and AEROsols (FIGAERO), Atmos. Meas. Tech., 7 , 983-1001, https://doi.org/10.5194/amt-7-983-2014, 2014.

Lopez-Hilfiker, F. D., Iyer, S., Mohr, C., Lee, B. H., D’ Ambro, E. L., Kurten, T., and Thornton, J. A.: Constraining the sensitivity of iodide adduct chemical ionization mass spectrometry to multifunctional organic molecules using the collision limit and thermodynamic stability of iodide ion adducts, Atmos. Meas. Tech. 9, 1505-1512, https://doi.org/10.5194/amt-9-1505-2016, 2016 a. Lopez-Hilfiker, F. D., Mohr, C., D’Ambro, E. L., Lutz, A., Riedel, T. P., Gaston, C. J., Iyer, S., Zhang, Z., Gold, A., Surratt, J. D., Lee, B. H., Kurten, T., Hu, W. W., Jimenez, J., Hallquist, M., and Thornton, J. A.: Molecular Composition and Volatility of Organic Aerosol in the Southeastern US: Implications for IEPOX Derived SOA, Environ. Sci. Technol., 50, 2200-2209, https://doi.org/10.1021/acs.est.5b04769, 2016b.

Min, K. E., Pusede, S. E., Browne, E. C., LaFranchi, B. W., Wooldridge, P. J., and Cohen, R. C.: Eddy covariance fluxes and vertical concentration gradient measurements of $\mathrm{NO}$ and $\mathrm{NO}_{2}$ over a ponderosa pine ecosystem: observational evidence for within-canopy chemical removal of $\mathrm{NO}_{x}$, Atmos. Chem. Phys., 14, 5495-5512, https://doi.org/10.5194/acp-145495-2014, 2014.

Mohr, C., Lopez-Hilfiker, F. D., Yli-Juuti, T., Heitto, A., Lutz, A., Hallquist, M., D’Ambro, E. L., Rissanen, M. P., Hao, L. Q., Schobesberger, S., Kulmala, M., Mauldin, R. L., Makkonen, U., Sipila, M., Petaja, T., and Thornton, J. A.: Ambient observations of dimers from terpene oxidation in the gas phase: Implications for new particle formation and growth, Geophys. Res. Lett., 44, 2958-2966, https://doi.org/10.1002/2017GL072718, 2017.

Nguyen, T. B., Laskin, J., Laskin, A., and Nizkorodov, S. A.: Nitrogen-Containing Organic Compounds and Oligomers 
in Secondary Organic Aerosol Formed by Photooxidation of Isoprene, Environ. Sci. Technol., 45, 6908-6918, https://doi.org/10.1021/es201611n, 2011.

Paasonen, P., Asmi, A., Petaja, T., Kajos, M. K., Aijala, M., Junninen, H., Holst, T., Abbatt, J. P. D., Arneth, A., Birmili, W., van der Gon, H. D., Hamed, A., Hoffer, A., Laakso, L., Laaksonen, A., Leaitch, W. R., Plass-Dulmer, C., Pryor, S. C., Raisanen, P., Swietlicki, E., Wiedensohler, A., Worsnop, D. R., Kerminen, V. M., and Kulmala, M.: Warming-induced increase in aerosol number concentration likely to moderate climate change, Nat. Geosci., 6, 438-442, https://doi.org/10.1038/Ngeo1800, 2013.

Paatero, P. and Tapper, U.: Positive matrix factorization: A non-negative factor model with optimal utilization of error estimates of data values, Environmetrics, 5, 111-126, https://doi.org/10.1002/env.3170050203, 1994.

Petäjä, T., O’Connor, E. J., Moisseev, D., Sinclair, V. A., Manninen, A. J., Vaananen, R., von Lerber, A., Thorntoton, J. A., Nicocoll, K., Petersen, W., Chandrasekar, V., Smith, J. N., Winkler, P. M., Kruger, O., Hakola, H., Timonen, H., Brus, D., Laurila, T., Asmi, E., Riekkola, M. L., Mona, L., Massoli, P., Engelmann, R., Komppppula, M., Wang, J., Kuang, C. G., Back, J., Virtanen, A., Levula, J., Ritsche, M., and Hickmon, N.: BAECC: A Field Campaign to Elucidate the Impact of Biogenic Aerosols on Clouds and Climate, B. Am. Meteorol. Soc., 97, 1909-1928, https://doi.org/10.1175/Bams-D-14-00199.1, 2016.

Riipinen, I., Pierce, J. R., Yli-Juuti, T., Nieminen, T., Hakkinen, S., Ehn, M., Junninen, H., Lehtipalo, K., Petaja, T., Slowik, J., Chang, R., Shantz, N. C., Abbatt, J., Leaitch, W. R., Kerminen, V. M., Worsnop, D. R., Pandis, S. N., Donahue, N. M., and Kulmala, M.: Organic condensation: a vital link connecting aerosol formation to cloud condensation nuclei (CCN) concentrations, Atmos. Chem. Phys., 11, 3865-3878, https://doi.org/10.5194/acp11-3865-2011, 2011.

Schobesberger, S., Lopez-Hilfiker, F. D., Taipale, D., Millet, D. B., D’Ambro, E. L., Rantala, P., Mammarella, I., Zhou, P. T., Wolfe, G. M., Lee, B. H., Boy, M., and Thornton, J. A.: High upward fluxes of formic acid from a boreal forest canopy, Geophys. Res. Lett., 43, 9342-9351, https://doi.org/10.1002/2016gl069599, 2016.

Seinfeld, J. H. and Pandis, S. N.: Atmospheric chemistry and physics : from air pollution to climate change, Third edition. ed., xxvi, 1120 pp., John Wiley \& Sons, Inc., Hoboken, New Jersey, 2016.

SMEAR: data available at: https://avaa.tdata.fi/web/smart/smear, last access: 30 July 2018.
Smolander, S., He, Q., Mogensen, D., Zhou, L., Back, J., Ruuskanen, T., Noe, S., Guenther, A., Aaltonen, H., Kulmala, M., and Boy, M.: Comparing three vegetation monoterpene emission models to measured gas concentrations with a model of meteorology, air chemistry and chemical transport, Biogeosciences, 11, 5425-5443, https://doi.org/10.5194/bg-11-5425-2014, 2014.

Spanke, J., Rannik, U., Forkel, R., Nigge, W., and Hoffmann, T.: Emission fluxes and atmospheric degradation of monoterpenes above a boreal forest: field measurements and modelling, Tellus B, 53, 406-422, https://doi.org/10.1034/j.16000889.2001.530407.x, 2001.

Spracklen, D. V. and Rap, A.: Natural aerosol-climate feedbacks suppressed by anthropogenic aerosol, Geophys. Res. Lett., 40, 5316-5319, https://doi.org/10.1002/2013GL057966, 2013.

Steffen, W., Noble, I., Canadell, J., Apps, M., Schulze, E. D., Jarvis, P. G., Baldocchi, D., Ciais, P., Cramer, W., Ehleringer, J., Farquhar, G., Field, C. B., Ghazi, A., Gifford, R., Heimann, M., Houghton, R., Kabat, P., Korner, C., Lambin, E., Linder, S., Mooney, H. A., Murdiyarso, D., Post, W. M., Prentice, I. C., Raupach, M. R., Schimel, D. S., Shvidenko, A., Valentini, R., and Grp, T. C. W.: The terrestrial carbon cycle: Implications for the Kyoto Protocol, Science, 280, 1393-1394, 1998.

Yan, C., Nie, W., Aijala, M., Rissanen, M. P., Canagaratna, M. R., Massoli, P., Junninen, H., Jokinen, T., Sarnela, N., Hame, S. A. K., Schobesberger, S., Canonaco, F., Yao, L., Prevot, A. S. H., Petaja, T., Kulmala, M., Sipila, M., Worsnop, D. R., and Ehn, M.: Source characterization of highly oxidized multifunctional compounds in a boreal forest environment using positive matrix factorization, Atmos. Chem. Phys., 16, 12715-12731, https://doi.org/10.5194/acp-16-12715-2016, 2016.

Yatavelli, R. L. N., Lopez-Hilfiker, F., Wargo, J. D., Kimmel, J. R., Cubison, M. J., Bertram, T. H., Jimenez, J. L., Gonin, M., Worsnop, D. R., and Thornton, J. A.: A Chemical Ionization High-Resolution Time-of-Flight Mass Spectrometer Coupled to a Micro Orifice Volatilization Impactor (MOVI-HRToF-CIMS) for Analysis of Gas and ParticlePhase Organic Species, Aerosol Sci. Tech., 46, 1313-1327, https://doi.org/10.1080/02786826.2012.712236, 2012.

Zha, Q., Yan, C., Junninen, H., Riva, M., Aalto, J., Quéléver, L., Schallhart, S., Dada, L., Heikkinen, L., Peräkylä, O., Zou, J., Rose, C., Wang, Y., Mammarella, I., Katul, G., Vesala, T., Worsnop, D. R., Kulmala, M., Petäjä, T., Bianchi, F., and Ehn, M.: Vertical characterization of Highly Oxygenated Molecules (HOMs) below and above a boreal forest canopy, Atmos. Chem. Phys. Discuss., https://doi.org/10.5194/acp-2017-1098, in review, 2017. 